Article

\title{
Antitumor Potential and Phytochemical Profile of Plants from Sardinia (Italy), a Hotspot for Biodiversity in the Mediterranean Basin
}

\author{
Concettina Cappadone ${ }^{1,+}{ }^{,}$Manuela Mandrone ${ }^{2, *,+}+\mathbb{C}$, Ilaria Chiocchio $^{2}$, Cinzia Sanna $^{3}$, \\ Emil Malucelli ${ }^{1}$ (D), Vincenza Bassi ${ }^{1}$, Giovanna Picone ${ }^{1}$ and Ferruccio Poli ${ }^{2}$ \\ 1 Department of Pharmacy and Biotechnology, University of Bologna, via San Donato 19/2, 40127 Bologna, \\ Italy; concettina.cappadone@unibo.it (C.C.); emil.malucelli@unibo.it (E.M.); \\ vincenza.bassi@studio.unibo.it (V.B.); giovanna.picone2@unibo.it (G.P.) \\ 2 Department of Pharmacy and Biotechnology, University of Bologna, Via Irnerio, 42, 40126 Bologna, Italy; \\ ilaria.chiocchio2@unibo.it (I.C.); ferruccio.poli@unibo.it (F.P.) \\ 3 Department of Life and Environmental Sciences, University of Cagliari, Via Sant'Ignazio da Laconi 13, \\ 09123 Cagliari, Italy; cinziasanna@unica.it \\ * Correspondence: manuela.mandrone2@unibo.it; Tel.: +39-051-2091294; Fax: +39-051-242576 \\ + These authors contribute equally to this work.
}

Received: 28 November 2019; Accepted: 22 December 2019; Published: 24 December 2019

\begin{abstract}
Sardinia (Italy), with its wide range of habitats and high degree of endemism, is an important area for plant-based drug discovery studies. In this work, the antitumor activity of 35 samples from Sardinian plants was evaluated on human osteosarcoma cells U2OS. The results showed that five plants were strongly antiproliferative: Arbutus unedo (AuL), Cynara cardunculus (CyaA), Centaurea calcitrapa (CcA), Smilax aspera (SaA), and Tanacetum audibertii (TaA), the latter endemic to Sardinia and Corsica. Thus, their ability to induce cell cycle arrest and apoptosis was tested. All extracts determined cell cycle block in G2/M phase. Nevertheless, the p53 expression levels were increased only by TaA. The effector caspases were activated mainly by CycA, TaA, and CcA, while AuL and SaA did not induce apoptosis. The antiproliferative effects were also tested on human umbilical vein endothelial cells (HUVEC). Except for AuL, all the extracts were able to reduce significantly cell population, suggesting a potential antiangiogenic activity. The phytochemical composition was first explored by ${ }^{1} \mathrm{H}$ NMR profiling, followed by further purifications to confirm the structure of the most abundant metabolites, such as phenolic compounds and sesquiterpene lactones, which might play a role in the measured bioactivity.
\end{abstract}

Keywords: Sardinian plants; antitumor activity; cell cycle; apoptosis; NMR profiling; sesquiterpene lactones

\section{Introduction}

Natural products (NP)-based drug discovery strongly benefits from research conducted in regions with high biodiversity and endemism [1,2]. In this context, Sardinia (Italy) deserves particular attention. This island is a hotspot for biodiversity, with a wide range of habitats and high degree of endemism, due to its geographical isolation and high geological and geomorphological diversification [3,4].

Sardinian flora consists of 2441 taxa [5], of which 295 taxa are endemic [6]. Among them, 189 are exclusive to Sardinia, 90 are Sardinian-Corsican endemics, and 16 taxa are also present in the Tuscan Archipelago [6]. Even though scientific evidence confirmed their interesting phytochemical and biological features [7-10], to date most Sardinian endemic plants remained scantly or not at all investigated. 
In addition, plant-based traditional medicine is still widely practiced and documented in Sardinia (Table 1). Ethnobotany plays also an important role in NP-based drug discovery, providing precious information about plant properties and uses, thus, increasing the chances to individuate active natural products with a good safety profile.

Several studies have demonstrated the role of medicinal plants in prevention and treatment of cancer [11], one of the leading causes of morbidity and mortality worldwide, responsible for one in eight deaths worldwide [12]. Chemotherapy and radiotherapy, routinely used for cancer treatment, are not devoid of their own intrinsic problems, such as the scarce selectivity toward cancer cells or the onset of drug resistance, requiring further research and treatment development. Next to common targets for tumor therapy, such as cell cycle inhibitors or proapoptotic agents, there are often angiogenesis modulators, especially in combined treatments [13]. The solid tumors, in fact, require an increased blood supply to support their growth, thus, angiogenesis is critical for the initiation, growth, and metastasis of these tumors [14].

As previously mentioned, in cancer treatment, the contribution of natural drugs has been both historically and currently remarkable [11,15]. Moreover, the preventive or antitumor activity of plant extracts was explored, attributing the result to the combined action of various phytochemicals rather than a single molecule $[16,17]$. Epidemiological studies also established associations between certain dietary patterns and reduced cancer risk $[18,19]$, and significant results were obtained in vitro and in vivo on different food secondary metabolites such as carotenoids, phenolic, and organosulfur compounds $[20,21]$.

On this basis, this work aimed at exploring the in vitro anticancer potential of a wide number of Sardinian plants, investigating the mechanisms of activity and the phytochemical profiles of the most active ones. 
Table 1. Ethnobotanical use of investigated plants in Sardinian traditional medicine. Up-to-date information on plants analyzed in this work. Traditional uses related to specific organs as well as preparation are reported.

\begin{tabular}{|c|c|c|c|}
\hline Plant Species & Plant Organ and Label & Ethnobotanical Use in Sardinia & Preparation \\
\hline \multirow{4}{*}{ Arbutus unedo L. } & \multirow[t]{2}{*}{ Fruits $(\mathrm{AuF})$} & $\begin{array}{l}\text { Astringent [22,23], blood circulation } \\
\text { (atherosclerosis) [24] }\end{array}$ & Decoction \\
\hline & & wound healing $[25,26]$ & Cataplasm \\
\hline & \multirow{2}{*}{ Leaves (AuL) } & Inflammations of intestine, kidney, bladder [25] & Decoction (together with fruits and roots) \\
\hline & & $\begin{array}{l}\text { Antipyretic, diarrhea [26-28], intestinal pains, as a } \\
\text { vulnerary [29], diuretic, against cystitis and } \\
\text { nephritis [22], asthma and bronchitis [28] }\end{array}$ & Decoction \\
\hline \multirow{3}{*}{$\begin{array}{c}\text { Asphodelus ramosus L. subsp } \\
\text { ramosus }\end{array}$} & \multirow{2}{*}{ Rhizome (ArRh) } & Sore throat, skin diseases [24] & Decoction \\
\hline & & $\begin{array}{c}\text { Skin disease (chilblain) [24,29], hemorrhoids and } \\
\text { impetigo [30] }\end{array}$ & Cataplasm \\
\hline & Leaves (ArL) & $\begin{array}{c}\text { Diuretic (not recommended for patients affected } \\
\text { by rheumatisms) [22] }\end{array}$ & Decoction \\
\hline Carlina gummifera (L.) Less. & Leaves $(\mathrm{CgL})$ & $\begin{array}{c}\text { Diuretic }[27,30] \text {, cholagogue, stomachic, and } \\
\text { diaphoretic [30] }\end{array}$ & Decoction and infusion \\
\hline \multirow[t]{2}{*}{ Centaurea calcitrapa $\mathrm{L}$. } & \multirow[t]{2}{*}{ Aerial parts (CcA) } & $\begin{array}{l}\text { Antipyretic, digestive, for constipation and } \\
\text { diarrhea }[22,31]\end{array}$ & Decoction \\
\hline & & Antiseptic [31] & Juice \\
\hline Centaurea horrida Badarò ${ }^{a}$ & Aerial parts (ChA) & N.D. * & - \\
\hline Centaurea napifolia $\mathrm{L}$. & Aerial parts (CnA) & $\begin{array}{l}\text { Nutritional purposes: aerial parts are often } \\
\text { included in the diet [32] }\end{array}$ & Direct ingestion \\
\hline Cistus monspeliensis $\mathrm{L}$. & Aerial parts $(\mathrm{CmA})$ & Topically for wound healing [30] & $\begin{array}{l}\text { Poultice obtained by pressing fresh } \\
\text { leaves between two pieces of wood }\end{array}$ \\
\hline Cistus salvifolius $\mathbf{L}$. & $\begin{array}{l}\text { Aerial parts } \\
\quad(\text { CsA) }\end{array}$ & N.D. * & - \\
\hline \multirow[t]{2}{*}{ Cynara cardunculus $\mathrm{L}$. } & \multirow[t]{2}{*}{ Aerial parts (CycA) } & $\begin{array}{c}\text { Hepatoprotective, blood depurative, } \\
\text { hypocholesterolemic, digestive, intestinal } \\
\text { spasmolytic }[24,33]\end{array}$ & Decoction \\
\hline & & Liver diseases [28] & Infusion \\
\hline
\end{tabular}


Table 1. Cont.

\begin{tabular}{|c|c|c|c|}
\hline Plant Species & Plant Organ and Label & Ethnobotanical Use in Sardinia & Preparation \\
\hline \multirow{2}{*}{ Ferula arrigonii Bocchieri ${ }^{b}$} & Leaves $(\mathrm{FaL})$ & N.D. * & - \\
\hline & $\begin{array}{l}\text { Roots } \\
(\mathrm{FaR})\end{array}$ & N.D. * & - \\
\hline Galactites tomentosa Moench & Aerial parts (GtA) & $\begin{array}{l}\text { Nutritional purposes: aerial parts are often } \\
\text { included in the diet [32] }\end{array}$ & Direct ingestion \\
\hline Genista corsica (Loisel.) $\mathrm{D}^{\mathrm{b}}$ & Aerial parts, flowers (GcA) & $\begin{array}{l}\text { In Corse, flowers were used as disinfectant of } \\
\text { wounds and abrasions [32] }\end{array}$ & Infusion \\
\hline Glechoma sardoa (Bég.) Bég. b & Aerial parts (GsA) & $\begin{array}{l}\text { Treatment of respiratory diseases, chronic catarrh, } \\
\text { bronchitis, asthma, and to heal wounds [22] }\end{array}$ & $\begin{array}{l}\text { Infusion of steam and flowers in water or } \\
\text { milk }\end{array}$ \\
\hline \multirow{2}{*}{$\begin{array}{l}\text { Hypericum hircinum L.ssp } \\
\text { hircinum }^{c}\end{array}$} & \multirow{2}{*}{ Aerial parts (HhA) } & Burns and wounds healing [22] & Macerated in olive oil \\
\hline & & $\begin{array}{c}\text { For rheumatic and sciatic pains and for } \\
\text { dislocations and sprains [22] }\end{array}$ & $\begin{array}{l}\text { Macerated in olive oil and white wine, } \\
\text { followed by evaporation of the wine }\end{array}$ \\
\hline $\begin{array}{l}\text { Hypericum scruglii Bacch., } \\
\text { Brullo \& Salmeri }^{\text {a }}\end{array}$ & $\begin{array}{l}\text { Aerial parts } \\
\quad(\mathrm{HsA})\end{array}$ & N.D. * & - \\
\hline \multirow{3}{*}{ Lavandula stoechas $\mathrm{L}$. } & \multirow{3}{*}{ Aerial parts (LsA) } & $\begin{array}{c}\text { Against ringworm and skin diseases, and for } \\
\text { wounds healing [22] }\end{array}$ & Macerated in spirit \\
\hline & & $\begin{array}{c}\text { Treatment of migraine, vertigo, asthma, } \\
\text { palpitation, whooping cough, laryngitis, } \\
\text { bronchitis, rheumatism [22,23], sedative, and skin } \\
\text { diseases [24] }\end{array}$ & Infusion \\
\hline & & Treatment of skin diseases [24] & Direct application of leaves \\
\hline $\begin{array}{c}\text { Limonium morisianum } \\
\text { Arrigoni }^{\text {a }}\end{array}$ & Aerial parts (LmA) & N.D. * & - \\
\hline
\end{tabular}


Table 1. Cont.

\begin{tabular}{|c|c|c|c|}
\hline Plant Species & Plant Organ and Label & Ethnobotanical Use in Sardinia & Preparation \\
\hline \multirow{7}{*}{ Myrtus communis $\mathrm{L}$. } & \multirow{3}{*}{ Fruits $(\mathrm{McF})$} & Vulnerary, cough, sedative, digestive [21] & Decoction \\
\hline & & Against cough and catarrh [25] and eupeptic [30] & Decoction (together with leaves) \\
\hline & & Digestive [25] & Macerated in spirit \\
\hline & \multirow{4}{*}{ Leaves (McL) } & Wound healing [30] & $\begin{array}{l}\text { Dried and powdered for topical } \\
\text { application }\end{array}$ \\
\hline & & $\begin{array}{l}\text { Digestive and as an agent to treat respiratory } \\
\text { ailments, as vulnerary, against hemorrhoids, to } \\
\text { treat sweaty feet [22], catarrhal cough [26] }\end{array}$ & Infusion \\
\hline & & $\begin{array}{l}\text { Digestive, treatment of respiratory inflammations } \\
\text { and hemorrhoids [22] }\end{array}$ & Fresh leaves pack \\
\hline & & $\begin{array}{l}\text { Vulnerary, cough, sedative, digestive [23], } \\
\text { bronchitis, and asthma [28] }\end{array}$ & Decoction \\
\hline \multirow{7}{*}{ Pistacia lentiscus L. } & \multirow{3}{*}{ Fruits (PIF) } & Cutaneous inflammations [30] & $\begin{array}{l}\text { Fresh-squeezed and heated for topical } \\
\text { application }\end{array}$ \\
\hline & & Halitosis [22] & Fresh fruits \\
\hline & & $\begin{array}{l}\text { Catarrhal cough, gingivitis, sore throat [30], } \\
\text { stomachache [28] }\end{array}$ & Decoction \\
\hline & \multirow{4}{*}{ Leaves (PlL) } & Treatment of gingivitis, sore throat [30] & $\begin{array}{l}\text { Decoction of fresh leaves to use as } \\
\text { mouthwash }\end{array}$ \\
\hline & & Stomatitis, cough sedative, skin diseases [24] & Decoction \\
\hline & & Against ticks [25] & Fumigation \\
\hline & & $\begin{array}{l}\text { Anticatarrhal [22], against cough and against bad } \\
\text { breath and as an antisudorific [29] }\end{array}$ & Infusion \\
\hline $\begin{array}{l}\text { Pistacia terebinthus L. ssp. } \\
\text { terebinthus }\end{array}$ & Leaves (PtL) & Catarrhal cough [26] & Decoction \\
\hline $\begin{array}{l}\text { Plagius flosculosus (L.) Alavi } \\
\text { \& Heywood }^{\text {b }}\end{array}$ & Aerial parts (PfA) & N.D. * & - \\
\hline $\begin{array}{l}\text { Ptilostermon casabonae (L.) } \\
\text { Greuter }{ }^{\mathrm{d}}\end{array}$ & Aerial parts (PcA) & Antispasmodic [32] & Direct ingestion \\
\hline
\end{tabular}


Table 1. Cont.

\begin{tabular}{|c|c|c|c|}
\hline Plant Species & Plant Organ and Label & Ethnobotanical Use in Sardinia & Preparation \\
\hline \multirow[t]{3}{*}{ Rosmarinus officinalis $\mathbf{L}$. } & \multirow[t]{3}{*}{ Aerial parts (RoA) } & $\begin{array}{c}\text { Stomachache [30], cholagogue, general tonic, } \\
\text { against common cold, hair loss [25], inappetence, } \\
\text { digestive, diuretic, sedative, headache, pruritus } \\
\text { [21] }\end{array}$ & Infusion \\
\hline & & $\begin{array}{l}\text { Hepatic [24], diarrhea [30], mucolytic, } \\
\text { anti-inflammatory, tooth care, colic, tonic for blood } \\
\text { pressure, joint pains [33], antitussive, } \\
\text { antispasmodic, migraine, digestive [25], taenifuge, } \\
\text { asthma, bronchitis; stomachic [28] }\end{array}$ & Decoction \\
\hline & & Antirheumatic [28] & Cataplasm \\
\hline $\begin{array}{l}\text { Santolina corsica Jord. \& } \\
\text { Fourr b }\end{array}$ & $\begin{array}{l}\text { Aerial parts } \\
\quad(\mathrm{ScA})\end{array}$ & N.D. * & \\
\hline $\begin{array}{c}\text { Scolymus hispanicus L. subsp. } \\
\text { hispanicus }\end{array}$ & Aerial parts (ShA) & $\begin{array}{l}\text { Nutritional purposes: young stems are often } \\
\text { included in the diet [32] }\end{array}$ & Direct ingestion \\
\hline $\begin{array}{l}\text { Silybum marianum (L.) } \\
\text { Gaertn. }\end{array}$ & $\begin{array}{l}\text { Aerial parts } \\
\quad(\mathrm{SmA})\end{array}$ & $\begin{array}{c}\text { Treatment of bleeding, diuretic, hypotensive, } \\
\text { sudorifer in case of pneumonia and chronic } \\
\text { catarrh [22] }\end{array}$ & Decoction (together with the seeds) \\
\hline \multirow{3}{*}{ Smilax aspera $\mathbf{L}$. } & \multirow{3}{*}{ Aerial parts $(\mathrm{SaA})$} & $\begin{array}{l}\text { Treatment of rheumatisms, skin diseases [24], } \\
\text { hemorrhoids [28] }\end{array}$ & Cataplasm \\
\hline & & Sudorific and blood cleanser $[24,27]$ & Decoction \\
\hline & & Toothache [28] & $\begin{array}{c}\text { Drops of fresh-squeezed juice applied on } \\
\text { the gums }\end{array}$ \\
\hline \multirow{2}{*}{ Stachys glutinosa L. $^{\mathrm{c}}$} & \multirow{2}{*}{ Aerial parts (SgA) } & Antiseptic, antispasmodic [32] & Infusion \\
\hline & & $\begin{array}{l}\text { Cholagogue, diuretic, and hepatoprotective [27], } \\
\text { common cold [28] }\end{array}$ & Decoction \\
\hline $\begin{array}{l}\text { Tanacetum audibertii (Req.) } \\
\text { DC }^{\mathbf{b}}\end{array}$ & Aerial parts $(\mathrm{TaA})$ & $\begin{array}{l}\text { Digestive, vermifuge, antiarthritic and to treat } \\
\text { menstrual disorders [30] }\end{array}$ & Decoction \\
\hline
\end{tabular}


Table 1. Cont

\begin{tabular}{|c|c|c|c|}
\hline Plant Species & Plant Organ and Label & Ethnobotanical Use in Sardinia & Preparation \\
\hline \multirow{5}{*}{ Thymus herba barona Loisel. e } & \multirow{5}{*}{$\begin{array}{l}\text { Aerial parts } \\
\quad(\mathrm{ThA})\end{array}$} & $\begin{array}{c}\text { Antitussive, expectorant, antispasmodic, collutory } \\
\text { [22], anthelmintic, treatment of stomachache [24], } \\
\text { sore throat, common cold, tonic and antianemic, } \\
\text { diuretic [28] }\end{array}$ & Decoction or infusion \\
\hline & & Against foot perspiration and urticaria [25] & Powder obtained by crushing aerial parts \\
\hline & & Rheumatisms [24] & Cataplasm \\
\hline & & Catarrhal, antipyretic [24] & Macerated in wine \\
\hline & & Lung diseases [24] & Vaporization \\
\hline
\end{tabular}




\section{Results and Discussion}

\subsection{Plant Traditional Uses and Screening of Antiproliferative Effect}

Firstly, a literature survey on uses in traditional Sardinian medicine of all the analyzed plants was conducted. The results are reported in Table 1.

Out of 30 plants, 18 resulted in being widely and commonly used for medicinal or nutritional purposes, while 13 are endemic and little known. For five of them (Centaurea horrida, Ferula arrigonii, Hypericum scruglii, Limonium morisianum, and Plagius flosculosus), there are no literature data available on their uses in traditional medicine, probably because of their rarity. They were included in the study for their importance as endemic species of Sardinia.

As a first line of screening, all plant extracts underwent MTT, 3-(4,5-dimethylthiazol-2-yl)-2,5diphenyltetrazolium bromide assay to evaluate their growth inhibition activity on U2OS cells. Cells were treated for $24 \mathrm{~h}$ with plant extracts at two fixed concentrations (50 and $100 \mu \mathrm{g} / \mathrm{mL}$ ), and the extracts which reduced cell growth by at least $20 \%$ were considered promisingly active and selected for further investigations. On this basis, five extracts significantly reduced osteosarcoma cell viability, namely: Arbutus unedo (AuL), Centaurea calcitrapa (CcA), Cynara cardunculus (CycA), Smilax aspera (SaA), Tanacetum audibertii (TaA) (Figure 1A).

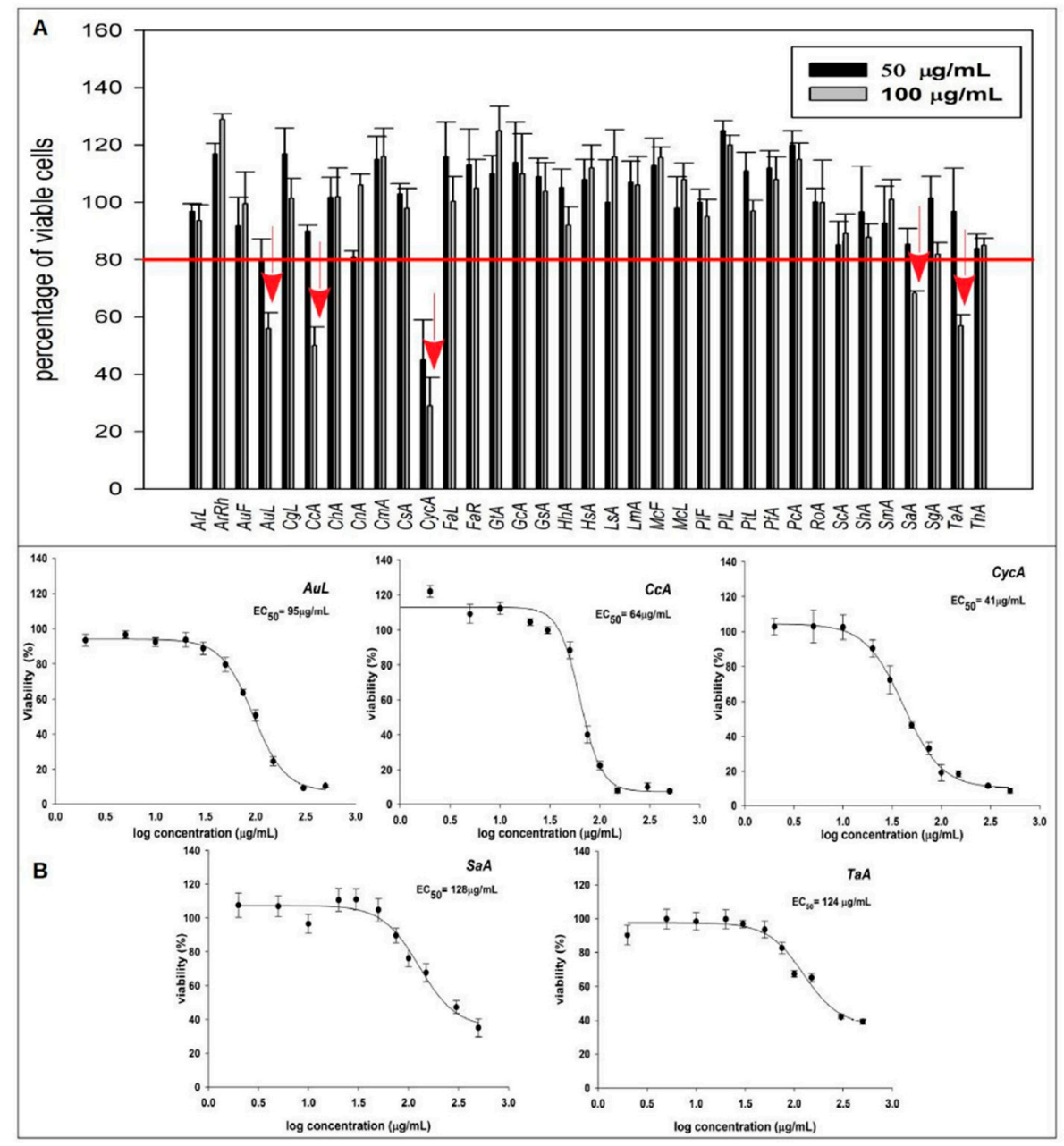

Figure 1. Antiproliferative effects of plant extracts on U2OS cells. (A) Screening of all extracts on viability of U2OS cells treated at 50 and $100 \mu \mathrm{g} / \mathrm{mL}$ concentrations. Bars indicate the means of six replicated experiments and represent the percentage of viable cells with respect to the control taken arbitrarily as $100 \%$. (B) Dose-response curves of U2OS cell viability after treatment with the five most active extracts for $48 \mathrm{~h}$. 
To calculate the $\mathrm{EC}_{50}$ concentration of the selected plants, dose-response curves at different times of treatment were performed (Table S1). The best-fitting sigmoidal function was obtained at $48 \mathrm{~h}$ of treatment (Figure 1B). Hence, all following experiments were carried out treating the cells for $48 \mathrm{~h}$ with the extracts at their $\mathrm{EC}_{50}$ concentration.

\subsection{Effect of the Selected Plants on the Cell Cycle Progression}

In order to investigate the mechanism of antiproliferative effects induced by the most active plant extracts, the cell cycle analysis was performed. Treated and control cells were stained with propidium iodide and analyzed by flow cytometry. All five extracts determined a block of cell population in G2/M phase, even though of different entities, and as a consequence a variation of cell percentage in G0/G1 and $\mathrm{S}$ phases. In particular, the increase of cell percentage in $\mathrm{G} 2 / \mathrm{M}$ phase became more consistent after treatment with CycA and TaA, reaching values above $50 \%$ (Figure $2 \mathrm{~A}$ ).

Several anticancer agents induce cell cycle arrest involving the pathway of the tumor suppressor p53 [34]; thus, the expression levels of this protein were analyzed by immunofluorescence after treatment with CycA and TaA. The TaA extract significantly affected p53 levels: the fluorescence mean channel went from 18 to 30 on a logarithmic scale, corresponding to an increase of the protein levels by $60 \%$ compared to the controls. On the contrary, CycA did not involve the $\mathrm{p} 53$ protein, as its levels in the treated cells were comparable to those of the controls (Figure 2B). Therefore, the two extracts exerted their effects through different mechanisms, involving various targets and signal transduction pathways. It is well known that many proapoptotic agents, including natural compounds and chemotherapeutics drugs, are able to induce apoptosis without any changes in p53 levels [35,36]. In particular, it is reported that doxorubicin-induced apoptosis on p53-null human osteosarcoma cells was characterized by an increase of ROS production, suggesting that ROS might act as the signal molecules even in the absence of p53 upstream cell death process [37].
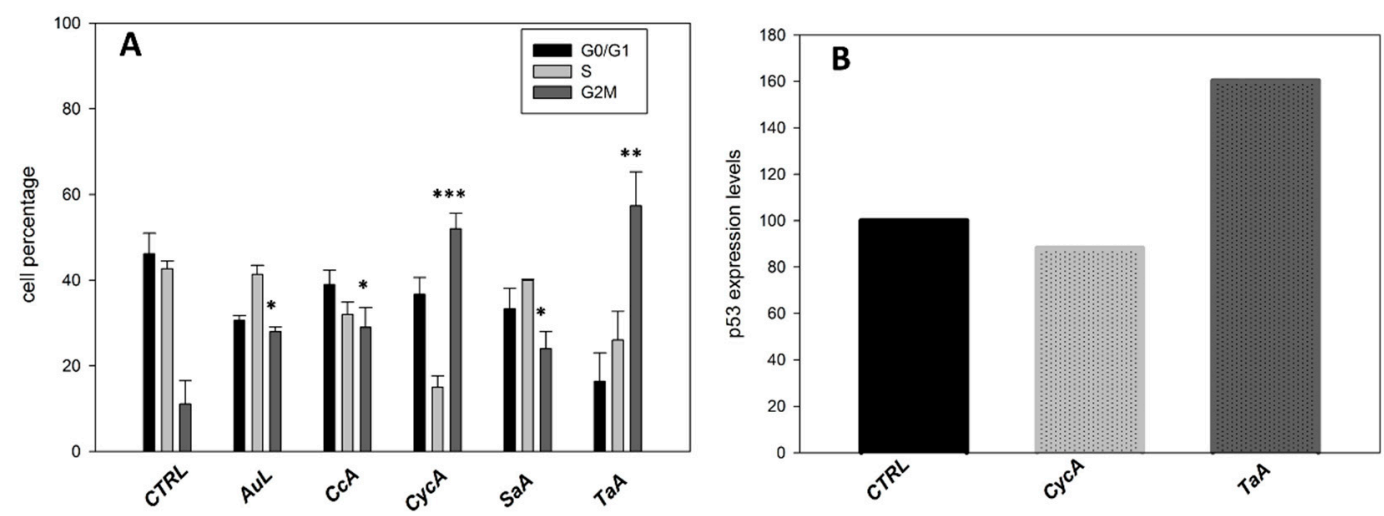

Figure 2. Effects of most potent plant extracts on cell cycle progression and p53 levels. (A) Cell cycle distribution of U2OS after $48 \mathrm{~h}$ of treatment with the plant extracts. Data are presented as means \pm $\mathrm{SD}$ of three different experiments. Differences were considered significant when $p \leq 0.05\left(^{*} p \leq 0.05\right.$; ${ }^{* *} p \leq 0.05 ;{ }^{* *} p \leq 0.001$ ). (B) Flow cytometric analysis of $\mathrm{p} 53$ protein levels after CycA or TaA treatment. The histograms represent the protein expression levels with respect to the control taken arbitrarily as $100 \%$. Results shown are representative data from three similar experiments.

\subsection{Assessment of Apoptotic Effect of Selected Extracts}

To give some insights into the biological effects of the active extracts, it was determined whether they induced apoptosis. Firstly, the morphology of the treated cells was evaluated. As expected, a significant reduction of adherent cells was visible as well as many floating cells, especially with CycA and TaA extracts (Figure 3A). Cells were stained with HOECHST nuclear probe to discriminate between apoptotic and necrotic death: the typical nuclear fragmentation of apoptotic cells, associated with 
the higher fluorescence intensity, was evident in treated samples, confirming the more prominent cytotoxicity of the CycA and TaA extracts (Figure 3B).

A

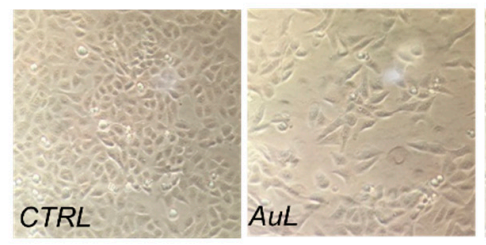

B

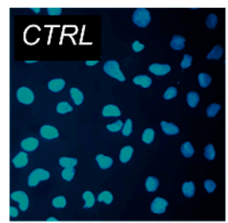

CycA

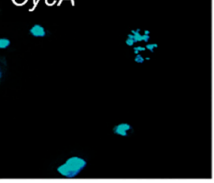

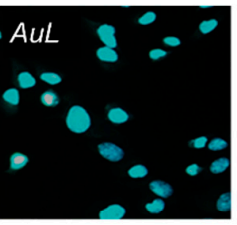

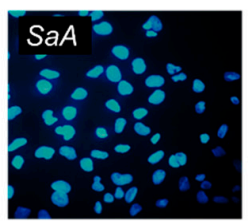

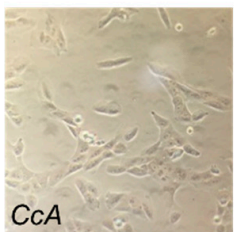

CycA

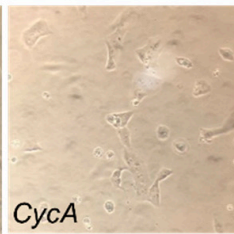

$\mathrm{SaA}$

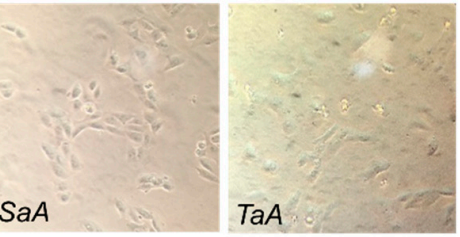

C
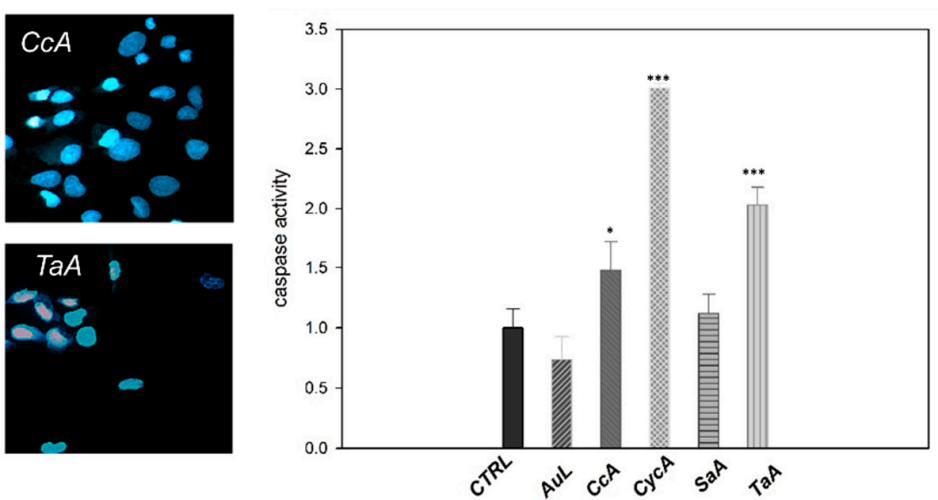

Figure 3. Apoptotic effects on U2OS cells treated for $48 \mathrm{~h}$ with the selected extracts: morphological changes and caspase activity. (A) Images acquired by optical microscope. (B) Images acquired by fluorescence microscope after HOECHST staining. (All the images were taken at the same magnification and depict microscopic fields representative of the whole cell population.) (C) Caspase activity assay (fold change of protein activity was calculated by taking untreated cells as a control =1). Bar graphs represent means \pm SD determined from at least three independent experiments. Differences were considered significant when $p \leq 0.05\left(^{*} p \leq 0.05 ;{ }^{* *} p \leq 0.001\right)$.

It is well known that activation of effector caspases represents a clear marker of apoptotic cell death [38]. Hence, to evaluate the apoptotic effect of the selected extracts on osteosarcoma cells, the caspase- 3 activity was determined. The histogram in Figure $3 \mathrm{C}$ shows that three plants triggered a significant caspase activation, although with different degrees. However, the higher induction was observed with CycA, followed by TaA and finally by CcA extracts. On the contrary, the antiproliferative effects of $\mathrm{AuL}$ and SaA extracts did not culminate in apoptotic events and these latter can be considered cytostatic rather than cytotoxic agents.

\subsection{Comparison of the Selected Plants' Effects on U2OS and HUVEC Cells}

A growing number of research has shown that angiogenesis is a hallmark of tumor development, becoming an attractive target for anticancer chemotherapy $[39,40]$. Furthermore, inhibiting angiogenesis before it starts (angio-prevention) allows blocking the expansion of hyperplastic foci and subsequent tumor development at the premalignant stage. Endothelial cell proliferation and migration are the key steps of the angiogenic process. Therefore, we investigated the effects of the most active extracts on the proliferation of human endothelial vein cells. As previously stated for Figure 1, a reduction of cell viability of at least $20 \%$ was considered significant. The data obtained clearly showed that four out of five tested extracts induced a marked cytotoxicity also in endothelial cells. In particular, CcA and CycA reduced the cell viability by $90 \%$ at both $50 \mu \mathrm{g} / \mathrm{mL}$ and $100 \mu \mathrm{g} / \mathrm{mL}$ concentrations. SaA and TaA reduced the viability by $30 \%$ and $50 \%$, respectively, only at $100 \mu \mathrm{g} / \mathrm{mL}$ concentration, similarly to osteosarcoma U2OS cells. Although this preliminary result requires further investigations, our findings suggest additional activity of these extracts, useful to contrast tumor growth. On the other 
hand, the lack of toxicity of AuL against HUVEC cells makes this extract interesting for the selectivity toward tumor cells (Table 2).

Table 2. Effects of five most active plant extracts on U2OS and HUVEC cell viability. Cells were treated at 50 and $100 \mu \mathrm{g} / \mathrm{mL}$ concentrations for $24 \mathrm{~h}$. Data are presented as means \pm SD of three replicated experiments and represent the percentage of viable cells with respect to the control taken arbitrarily as $100 \%$.

\begin{tabular}{lllll}
\hline Extracts & U2OS Cells & \multicolumn{3}{l}{ HUVEC Cells } \\
\hline & $50 \mu \mathrm{g} / \mathrm{mL}$ & $100 \mu \mathrm{g} / \mathrm{mL}$ & $50 \mu \mathrm{g} / \mathrm{mL}$ & $100 \mu \mathrm{g} / \mathrm{mL}$ \\
AuL & $79.6 \pm 7.7$ & $56 \pm 5.5$ & $111.8 \pm 0.63$ & $104.7 \pm 4.6$ \\
CcA & $90 \pm 2$ & $50 \pm 6.5$ & $6.5 \pm 0.29$ & $6.4 \pm 0.05$ \\
CycA & $45 \pm 1.4$ & $29 \pm 9.9$ & $6.5 \pm 0.02$ & $7.7 \pm 0.37$ \\
SaA & $85.4 \pm 5.5$ & $68.3 \pm 0.7$ & $114.2 \pm 0.08$ & $77.3 \pm 1.11$ \\
TaA & $96.9 \pm 12.9$ & $56.9 \pm 3.9$ & $98.9 \pm 0.07$ & $50.4 \pm 1.5$ \\
\hline
\end{tabular}

\subsection{Phytochemical Analyses}

Since the results showed that Arbutus unedo (leaves) (AuL), Cynara cardunculus (aerial parts) (CycA), Centaurea calcitrapa (aerial parts) (CcA), Smilax aspera (aerial parts) (SaA), and Tanacetum audibertii (aerial parts) ( $\mathrm{TaA}$ ) were promising for their biological activities, they were subjected to further phytochemical investigations. Three of them (CycA, CcA, TaA) belong to the Asteraceae family and, among them, T. audibertii is endemic to Sardinia and Corsica.

Firstly, ${ }^{1} \mathrm{H}$ NMR profiling was performed to acquire a preliminary overview of the main metabolites present in the extracts (Figure 4). Both secondary and primary metabolites (such as amino acids, carbohydrates, and organic acids) were detected in the extracts (diagnostic ${ }^{1} \mathrm{H}$ NMR signals are listed in Table S2 in SI). The content of the main metabolites was then determined, on the basis of the internal standard TMSP, as reported in Table 3.

Regarding secondary metabolites, AuL showed a high concentration of arbutin, a glycoside hydroquinone which is considered the main active principle of this plant [41]. The NMR profiling highlighted also the presence of $O$-rhamnosyl flavonoid, showing typical signals of $\alpha$-rhamnose, namely the doublet of the methyl group resonating around $\delta 0.89$. Both arbutin and flavonoids might play a role in the measured biological activities [42,43].

Since, in the first screening, both leaves (AuL) and fruits (AuF) of Arbutus unedo were tested, and only leaves were found active, the ${ }^{1} \mathrm{H}$ NMR-based phytochemical profiles of these two samples were also compared. The profile of AuF lacked both arbutin and rhamnosyl flavonoid signals (Figure S1), supporting the importance of these compounds for the bioactivity of AuL.

From the ${ }^{1} \mathrm{H}$ NMR profile of CycA, the guaiane-type sesquiterpene lactone cynaropicrin resulted in being the most abundant metabolite (see Table A1 and Figure S2 for structure elucidation).

Interestingly, despite its high lipophilicity, this compound was found highly concentrated $\left(159.4 \mu \mathrm{g} / \mathrm{mg}\right.$ of extract) in the extract solubilized in $\mathrm{D}_{2} \mathrm{O}$-buffer. This phenomenon is quite common in natural products chemistry, since the inclusion of a lipophilic compound in a complex mixture of metabolites, such as a plant extract, often increases its solubility in water [44]. The discrete concentration of cynaropicrin found in the water medium is interesting also because CycA is traditionally prepared in the form of a decoction or infusion (Table 1).

Cynaropicrin is potentially one of the most important active principles responsible for the bioactivity of CycA [45]. Similarly to CycA, the bioactivity of the other plants belonging to Asteraceae might be due to sesquiterpene lactones, which are typical of this plant family, and are reported to possess antitumor potential [46]. Moreover, several studies report the ability of these plant extracts to inhibit the proliferation mainly of breast cancer cells, but also of hematological cancer [47,48]. 

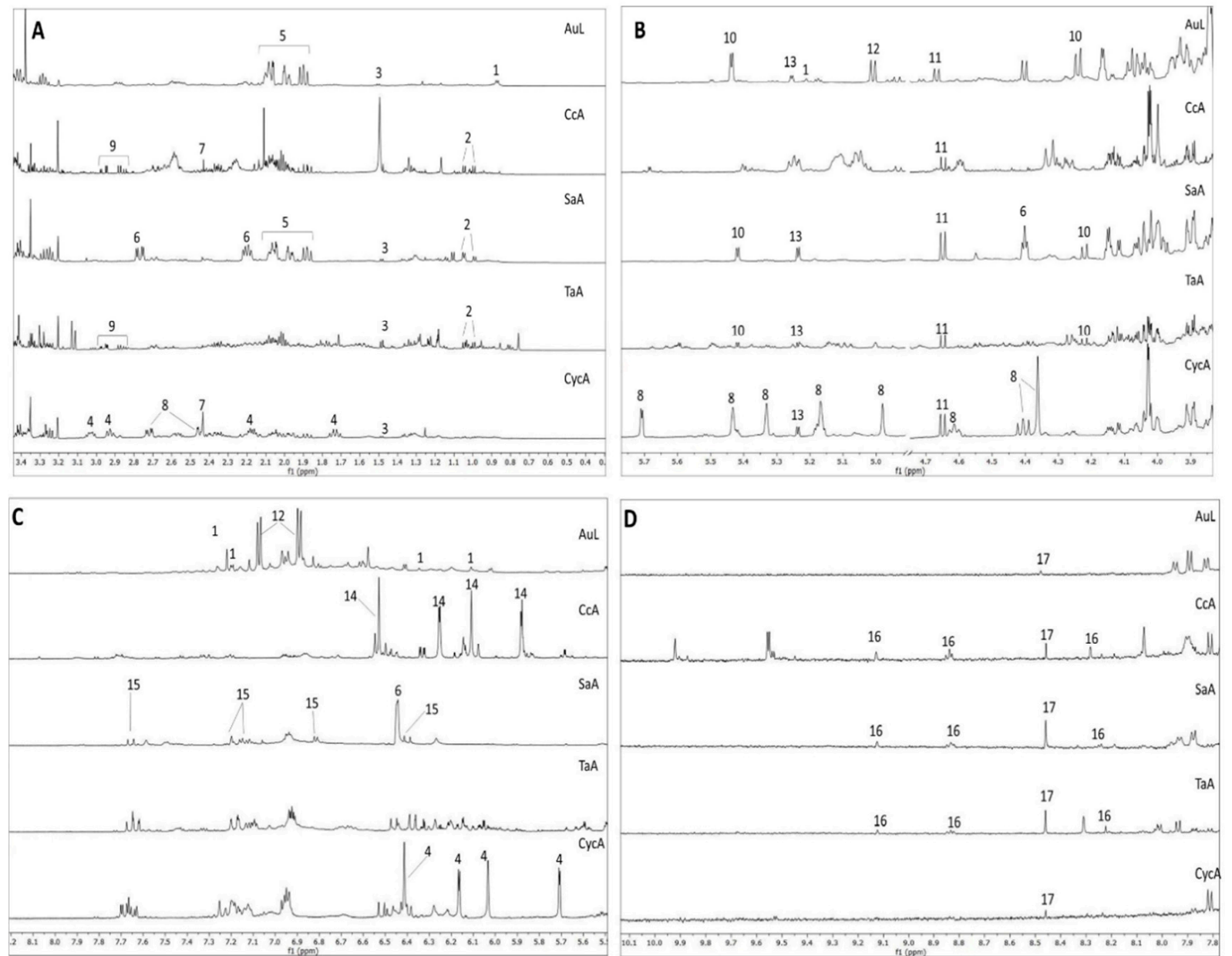

Figure 4. ${ }^{1} \mathrm{H}$ NMR extended spectral regions of AuL; CcA; SaA; TaA; CycA (from top to bottom). (A) region from $\delta 0.4$ to $3.4 ;$ (B) from $\delta 3.4$ to 5.4 ; (C) from $\delta 5.4$ to 8.1; (D) from $\delta 7.8$ to 10.00. Numbers indicate diagnostic signals of the most abundant metabolites: O-rhamnosyl flavonoid (1), valine (2), alanine (3), cynaropicrin (4), quinic acid (5), shikimic acid (6), succinic acid (7), malic acid (8), aspartic acid (9), sucrose (10), $\beta$-glucose (11), arbutin (12), $\alpha$-glucose (13), sesquiterpene lactone-derivative (14), caffeic acid (15), trigonelline (16), formic acid (17). Spectra were measured in $\mathrm{D}_{2} \mathrm{O}-\mathrm{buffer}(\mathrm{pH}$ 6.0) using TMSP as standard, residual water signal has been removed. 
Table 3. Estimated amount of metabolites by ${ }^{1} \mathrm{H}$ NMR analysis.

\begin{tabular}{|c|c|c|c|c|c|c|}
\hline \multirow{2}{*}{ Metabolite } & \multirow{2}{*}{$\begin{array}{l}\text { Diagnostic }{ }^{1} \mathrm{H} \text { NMR Signal }(\delta) \text { Used for the Quantification and } \\
\text { Number of Underlying Proton/s (in Brackets) }\end{array}$} & \multicolumn{5}{|c|}{ Metabolite Quantity in the Extract ( $\mu \mathrm{g} / \mathrm{mg}$ of Extract) } \\
\hline & & AuL & CycA & $\mathrm{CcA}$ & $\mathrm{TaA}$ & SaA \\
\hline alanine & $1.48(3 \mathrm{H})$ & 1.4 & 2.0 & - & 8.9 & 3.7 \\
\hline arbutin & $7.07(2 \mathrm{H})$ & 75 & - & - & - & - \\
\hline aspartate & $2.96(1 \mathrm{H})$ & - & - & 17 & 33 & - \\
\hline caffeic acid & $7.62(1 \mathrm{H})$ & - & - & - & - & 13 \\
\hline cynaropicrin & $6.16(1 \mathrm{H})$ & - & 159 & - & - & - \\
\hline$\alpha$-glucose & $5.2(1 \mathrm{H})$ & 22 & 24 & - & - & 40 \\
\hline$\beta$-glucose & $4.59(1 \mathrm{H})$ & 36 & 49 & - & 34 & 88 \\
\hline isoleucine & $1.06(3 \mathrm{H})$ & - & - & - & - & 19 \\
\hline quinic acid & $1.87(1 \mathrm{H})$ & 142 & 43 & - & - & 193 \\
\hline shikimic acid & $6.45(1 \mathrm{H})$ & - & - & - & - & 141 \\
\hline sucrose & $5.4(1 \mathrm{H})$ & 138 & - & - & 45 & 79 \\
\hline
\end{tabular}


Regarding CcA, the ${ }^{1} \mathrm{H}$ NMR profile clearly presented signals ascribable to sesquiterpene lactones [48]. In particular, the geminal protons of the double bond in position 13 on the $\gamma$-lactone were clearly visible in the CcA profile. They showed two doublets with chemical shift of $\delta 6.05$ and 5.59 and coupling constant of $3.23 \mathrm{~Hz}$ (calculated by J-res experiment), with HSQC correlation to the carbon at $\delta$ 119.24 , and HMBC and COSY correlation to carbon at $\delta 52.72$ and proton at $\delta 3.08$, respectively, which are characteristic chemical shifts of position 7 of this nucleus. The latter carbon, in turn, showed HMBC correlation to a proton resonating at $\delta 2.50$ (linked to carbon at $\delta 51.41$ ), which is typical of position 5 of the molecule (Figures S3 and S4). High antioxidant and cytotoxicity activities on HeLa and Vero cell lines were reported for Centaurea calcitrapa [49]. Our results confirm the capability of the hydroalcoholic plant extract to inhibit cell proliferation on another cell type, highly proliferating and undifferentiated such as the U2OS cell line.

Interestingly, in this work, two other species of Centaurea were tested (CnA and ChA) showing no relevant bioactivity. The ${ }^{1} \mathrm{H}$ NMR profiles of all three Centaurea species were recorded and compared. In the ChA profile, no signals ascribable to $\gamma$-lactone were visible, while in $\mathrm{CnA}$, they were present, showing a lower intensity compared to the CcA profile (Figure S5 in SI). This data might support the importance of these compounds for the measured bioactivity.

The phytochemical profile of SaA showed a high quantity of shikimic acid and quinic acid, together with caffeic acid. There are very few studies on potential antiproliferative of Smilax aspera. It is reported that steroidal saponins and anthocyanins have been isolated from this plant, and that some of these compounds exhibit cytotoxic activity against human normal amniotic and human lung carcinoma cell lines $[50,51]$. We demonstrated that it induces cytostatic effects on osteosarcoma cells.

Moreover, flavonoid and phenolic content of the five selected plants were determined, and the results were compared by one-way ANOVA test (Figure S6). The phenolic content ranged from 76.97 to $25.68 \mathrm{mg}$ GAE/g of extract, with the following order of concentration: AuL $>\mathrm{SaA}>\mathrm{TaA}>$ CycA > CcA. Total flavonoid content ranged from 52.3 to $16.09 \mathrm{mg} \mathrm{RE} / \mathrm{g}$ of extract. No significant differences were found among the samples, with the exception of TaA, which resulted as the extract with the highest content of flavonoids. It is noteworthy that samples treated with this latter extract showed a marked apoptosis induction, characterized by significant G2/M arrest and increased p53 level. The high phenolic content could explain the clear proapoptotic effect, as it is well known that this class of compounds is able to induce apoptosis via the p53 pathway [39]. Our work demonstrated for the first time the antitumor potential of Tanacetum audibertii, as only antifungal properties have been documented in the literature [52].

\section{Materials and Methods}

\subsection{Chemicals}

All reagents were purchased from Sigma Aldrich (Milano, Italy), except the deuterated solvents, which were purchased by Eurisotop (Cambridge, UK).

\subsection{Plant Material}

All plants were collected at the flowering stage. Species were botanically identified by Dr. Cinzia Sanna and voucher specimens were deposited at the General Herbarium of the Department of Life and Environmental Sciences, University of Cagliari (Table 4). Regarding selected endemic species, they are not protected by local or international regulations. Furthermore, the locations where they were harvested are not included in national or local parks or any other natural protected areas. Therefore, no specific permission was required for their collection. 
Table 4. List of the plants analyzed in this work. Plant name, family, considered plant organ and adopted label, harvesting date and GPS coordinates, and voucher number are reported.

\begin{tabular}{|c|c|c|c|c|c|}
\hline Plant Name & Family & $\begin{array}{c}\text { Plant Organ and } \\
\text { Sample Label in } \\
\text { Brackets }\end{array}$ & $\begin{array}{c}\text { GPS } \\
\text { Coordinates }\end{array}$ & $\begin{array}{c}\text { HARVESTING } \\
\text { DATE }\end{array}$ & Voucher \\
\hline \multirow[t]{2}{*}{ Arbutus unedo L. } & \multirow[t]{2}{*}{ Ericaceae } & Fruits (AuF) & $\begin{array}{c}39^{\circ} 45^{\prime} 37.8^{\prime \prime} \mathrm{N} \\
9^{\circ} 30^{\prime} 31.0^{\prime \prime} \mathrm{E}\end{array}$ & December 2017 & \multirow[t]{2}{*}{$\begin{array}{c}\text { Herbarium } \\
\text { CAG } 878\end{array}$} \\
\hline & & Leaves (AuL) & $\begin{array}{c}39^{\circ} 45^{\prime} 37.8^{\prime \prime} \mathrm{N} \\
9^{\circ} 30^{\prime} 31.0^{\prime \prime} \mathrm{E}\end{array}$ & December 2017 & \\
\hline \multirow{2}{*}{$\begin{array}{c}\text { Asphodelus } \\
\text { ramosus L. subsp. } \\
\text { ramosus }\end{array}$} & \multirow[t]{2}{*}{ Asphodelaceae } & Rhizome (ArRh) & $\begin{array}{c}39^{\circ} 10^{\prime} 38.7^{\prime \prime} \mathrm{N} \\
9^{\circ} 22^{\prime} 50.3^{\prime \prime} \mathrm{E}\end{array}$ & April 2017 & \multirow{2}{*}{$\begin{array}{l}\text { Herbarium } \\
\text { CAG } 1405\end{array}$} \\
\hline & & Leaves (ArL) & $\begin{array}{c}39^{\circ} 10^{\prime} 38.7^{\prime \prime} \mathrm{N} \\
9^{\circ} 22^{\prime} 50.3^{\prime \prime} \mathrm{E}\end{array}$ & April 2017 & \\
\hline $\begin{array}{l}\text { Carlina gummifera } \\
\text { (L.) Less. }\end{array}$ & Asteraceae & Leaves (CgL) & $\begin{array}{c}39^{\circ} 45^{\prime} 44.2^{\prime \prime} \mathrm{N} \\
9^{\circ} 40^{\prime} 16.9^{\prime \prime} \mathrm{E}\end{array}$ & July 2018 & $\begin{array}{l}\text { Herbarium } \\
\text { CAG } 770\end{array}$ \\
\hline $\begin{array}{c}\text { Centaurea } \\
\text { calcitrapa } \mathrm{L} .\end{array}$ & Asteraceae & Aerial parts (CcA) & $\begin{array}{c}39^{\circ} 18^{\prime} 02.3^{\prime \prime} \mathrm{N} \\
8^{\circ} 53^{\prime} 39.4^{\prime \prime} \mathrm{E}\end{array}$ & June 2017 & $\begin{array}{l}\text { Herbarium } \\
\text { CAG } 781\end{array}$ \\
\hline $\begin{array}{c}\text { Centaurea horrida } \\
\text { Badarò * }\end{array}$ & Asteraceae & Aerial parts (ChA) & $\begin{array}{c}40^{\circ} 57^{\prime} 51.6^{\prime \prime} \mathrm{N} \\
8^{\circ} 12^{\prime} 05.0^{\prime \prime} \mathrm{E}\end{array}$ & June 2017 & $\begin{array}{l}\text { Herbarium } \\
\text { CAG } 777\end{array}$ \\
\hline $\begin{array}{c}\text { Centaurea } \\
\text { napifolia } \mathrm{L} .\end{array}$ & Asteraceae & Aerial parts $(\mathrm{CnA})$ & $\begin{array}{c}39^{\circ} 16^{\prime} 51.5^{\prime \prime} \mathrm{N} \\
8^{\circ} 56^{\prime} 01.5^{\prime \prime} \mathrm{E}\end{array}$ & June 2017 & $\begin{array}{l}\text { Herbarium } \\
\text { CAG } 784\end{array}$ \\
\hline $\begin{array}{c}\text { Cistus } \\
\text { monspeliensis L. }\end{array}$ & Cistaceae & Aerial parts (CmA) & $\begin{array}{c}39^{\circ} 45^{\prime} 44.2^{\prime \prime} \mathrm{N} \\
9^{\circ} 40^{\prime} 16.9^{\prime \prime} \mathrm{E}\end{array}$ & April 2018 & $\begin{array}{l}\text { Herbarium } \\
\text { CAG } 135\end{array}$ \\
\hline $\begin{array}{c}\text { Cistus salviifolius } \\
\text { L. }\end{array}$ & Cistaceae & Aerial parts (CsA) & $\begin{array}{c}39^{\circ} 45^{\prime} 44.2^{\prime \prime} \mathrm{N} \\
9^{\circ} 40^{\prime} 16.9^{\prime \prime} \mathrm{E}\end{array}$ & April 2018 & $\begin{array}{l}\text { Herbarium } \\
\text { CAG 135/C }\end{array}$ \\
\hline $\begin{array}{c}\text { Cynara } \\
\text { cardunculus L. }\end{array}$ & Asteraceae & Aerial parts (CycA) & $\begin{array}{c}39^{\circ} 18^{\prime} 02.3^{\prime \prime} \mathrm{N} \\
8^{\circ} 53^{\prime} 39.4^{\prime \prime} \mathrm{E}\end{array}$ & April 2017 & $\begin{array}{l}\text { Herbarium } \\
\text { CAG } 790\end{array}$ \\
\hline \multirow[t]{2}{*}{$\begin{array}{c}\text { Ferula arrigonii } \\
\text { Bocchieri } * *\end{array}$} & \multirow[t]{2}{*}{ Apiaceae } & Leaves (FaL) & $\begin{array}{c}39^{\circ} 51^{\prime} 37.9^{\prime \prime} \mathrm{N} \\
8^{\circ} 26^{\prime} 05.2^{\prime \prime} \mathrm{E}\end{array}$ & April 2017 & \multirow[t]{2}{*}{$\begin{array}{l}\text { Herbarium } \\
\text { CAG 612/A }\end{array}$} \\
\hline & & Roots (FaR) & $\begin{array}{c}39^{\circ} 51^{\prime} 37.9^{\prime \prime} \mathrm{N} \\
8^{\circ} 26^{\prime} 05.2^{\prime \prime} \mathrm{E}\end{array}$ & April 2017 & \\
\hline $\begin{array}{l}\text { Galactites } \\
\text { tomentosa } \\
\text { Moench }\end{array}$ & Asteraceae & Aerial parts (GtA) & $\begin{array}{c}39^{\circ} 46^{\prime} 16.7^{\prime \prime} \mathrm{N} \\
9^{\circ} 30^{\prime} 41.6^{\prime \prime} \mathrm{E}\end{array}$ & September 2018 & $\begin{array}{l}\text { Herbarium } \\
\text { CAG } 789\end{array}$ \\
\hline $\begin{array}{l}\text { Genista corsica } \\
\text { (Loisel.) DC ** }\end{array}$ & Fabaceae & Aerial parts (GcA) & $\begin{array}{c}39^{\circ} 49^{\prime} 35.0^{\prime \prime} \mathrm{N} \\
9^{\circ} 20^{\prime} 27.5^{\prime \prime} \mathrm{E}\end{array}$ & May 2017 & $\begin{array}{l}\text { Herbarium } \\
\text { CAG } 286\end{array}$ \\
\hline $\begin{array}{l}\text { Glechoma sardoa } \\
\text { (Bég.) Bég ** }\end{array}$ & Lamiaceae & Aerial parts (GsA) & $\begin{array}{c}39^{\circ} 57^{\prime} 33.5^{\prime \prime} \mathrm{N} \\
9^{\circ} 19^{\prime} 13.3^{\prime \prime} \mathrm{E}\end{array}$ & June 2017 & $\begin{array}{l}\text { Herbarium } \\
\text { CAG } 1104\end{array}$ \\
\hline $\begin{array}{c}\text { Hypericum } \\
{\text { hircinum } \text { L. } s p}^{\text {hircinum }^{+}}\end{array}$ & Hypericaceae & Aerial parts (HhA) & $\begin{array}{c}39^{\circ} 46^{\prime} 55.8^{\prime \prime} \mathrm{N} \\
9^{\circ} 30^{\prime} 52.5^{\prime \prime} \mathrm{E}\end{array}$ & June 2018 & $\begin{array}{l}\text { Herbarium } \\
\text { CAG } 232\end{array}$ \\
\hline $\begin{array}{c}\text { Hypericum scruglii } \\
\text { Bacch., Brullo \& } \\
\text { Salmeri }\end{array}$ & Hypericaceae & Aerial parts (HsA) & $\begin{array}{c}39^{\circ} 45^{\prime} 57.4^{\prime \prime} \mathrm{N} \\
9^{\circ} 30^{\prime} 41.8^{\prime \prime} \mathrm{E}\end{array}$ & June 2018 & $\begin{array}{l}\text { Herbarium } \\
\text { CAG 239/C }\end{array}$ \\
\hline $\begin{array}{l}\text { Lavandula } \\
\text { stoechas } \mathrm{L} .\end{array}$ & Lamiaceae & Aerial parts (LsA) & $\begin{array}{c}39^{\circ} 45^{\prime} 44.2^{\prime \prime} \mathrm{N} \\
9^{\circ} 40^{\prime} 16.9^{\prime \prime} \mathrm{E}\end{array}$ & April 2017 & $\begin{array}{l}\text { Herbarium } \\
\text { CAG } 1067\end{array}$ \\
\hline $\begin{array}{l}\text { Limonium } \\
\text { morisianum } \\
\text { Arrigoni * }\end{array}$ & Plumbaginaceae & Aerial parts (LmA) & $\begin{array}{c}39^{\circ} 54^{\prime} 33.3^{\prime \prime} \mathrm{N} \\
9^{\circ} 24^{\prime} 41.0^{\prime \prime} \mathrm{E}\end{array}$ & December 2017 & $\begin{array}{l}\text { Herbarium } \\
\text { CAG 909/G }\end{array}$ \\
\hline
\end{tabular}


Table 4. Cont.

\begin{tabular}{|c|c|c|c|c|c|}
\hline Plant Name & Family & $\begin{array}{c}\text { Plant Organ and } \\
\text { Sample Label in } \\
\text { Brackets }\end{array}$ & $\begin{array}{c}\text { GPS } \\
\text { Coordinates }\end{array}$ & $\begin{array}{c}\text { HARVESTING } \\
\text { DATE }\end{array}$ & Voucher \\
\hline \multirow{2}{*}{$\begin{array}{l}\text { Myrtus communis } \\
\text { L. }\end{array}$} & \multirow[t]{2}{*}{ Myrtaceae } & Fruits (McF) & $\begin{array}{c}39^{\circ} 45^{\prime} 44.2^{\prime \prime} \mathrm{N} \\
9^{\circ} 40^{\prime} 16.9^{\prime \prime} \mathrm{E}\end{array}$ & December 2018 & \multirow[t]{2}{*}{$\begin{array}{c}\text { Herbarium } \\
\text { CAG } 514\end{array}$} \\
\hline & & Leaves (McL) & $\begin{array}{c}39^{\circ} 08^{\prime} 22.2^{\prime \prime} \mathrm{N} \\
8^{\circ} 58^{\prime} 08.9^{\prime \prime} \mathrm{E}\end{array}$ & April 2018 & \\
\hline \multirow{2}{*}{$\begin{array}{c}\text { Pistacia lentiscus } \\
\text { L. }\end{array}$} & \multirow[t]{2}{*}{ Anacardiaceae } & Fruits (PIF) & $\begin{array}{c}39^{\circ} 45^{\prime} 44.2^{\prime \prime} \mathrm{N} \\
9^{\circ} 40^{\prime} 16.9^{\prime \prime} \mathrm{E}\end{array}$ & December 2017 & \multirow{2}{*}{$\begin{array}{l}\text { Herbarium } \\
\text { CAG } 280\end{array}$} \\
\hline & & Leaves (PlL) & & December 2017 & \\
\hline $\begin{array}{c}\text { Pistacia } \\
\text { terebinthus L. ssp. } \\
\text { terebinthus }\end{array}$ & Anacardiaceae & Leaves (PtL) & $\begin{array}{c}39^{\circ} 47^{\prime} 38.8^{\prime \prime} \mathrm{N} \\
9^{\circ} 30^{\prime} 38.3^{\prime \prime} \mathrm{E}\end{array}$ & June 2018 & $\begin{array}{l}\text { Herbarium } \\
\text { CAG } 279\end{array}$ \\
\hline $\begin{array}{c}\text { Plagius } \\
\text { flosculosus ( L.) } \\
\text { Alavi \& Heywood } \\
\qquad * *\end{array}$ & Asteraceae & Aerial parts (PfA) & $\begin{array}{c}39^{\circ} 21^{\prime} 45.2^{\prime \prime} \mathrm{N} \\
8^{\circ} 32^{\prime} 24.1^{\prime \prime} \mathrm{E}\end{array}$ & July 2017 & $\begin{array}{l}\text { Herbarium } \\
\text { CAG } 743\end{array}$ \\
\hline $\begin{array}{l}\text { Ptilostemon } \\
\text { casabonae (L.) } \\
\text { Greuter }^{++}\end{array}$ & Asteraceae & Aerial parts (PcA) & $\begin{array}{c}39^{\circ} 53^{\prime} 52.7^{\prime \prime} \mathrm{N} \\
9^{\circ} 26^{\prime} 31.8^{\prime \prime} \mathrm{E}\end{array}$ & June 2018 & $\begin{array}{l}\text { Herbarium } \\
\text { CAG } 796\end{array}$ \\
\hline $\begin{array}{l}\text { Rosmarinus } \\
\text { officinalis L. }\end{array}$ & Lamiaceae & Aerial parts (RoA) & $\begin{array}{c}40^{\circ} 34^{\prime} 10.1^{\prime \prime} \mathrm{N} \\
8^{\circ} 22^{\prime} 57.0^{\prime \prime} \mathrm{E}\end{array}$ & May 2017 & $\begin{array}{l}\text { Herbarium } \\
\text { CAG } 1091\end{array}$ \\
\hline $\begin{array}{l}\text { Santolina corsica } \\
\text { Jord. \& Fourr** }\end{array}$ & Asteraceae & Aerial parts (ScA) & $\begin{array}{c}40^{\circ} 32^{\prime} 30.6^{\prime \prime} \mathrm{N} \\
9^{\circ} 36^{\prime} 09.4^{\prime \prime} \mathrm{E}\end{array}$ & November 2017 & $\begin{array}{l}\text { Herbarium } \\
\text { CAG 732/A }\end{array}$ \\
\hline $\begin{array}{c}\text { Scolymus } \\
\text { hispanicus L. } \\
\text { subsp. hispanicus }\end{array}$ & Asteraceae & Aerial parts (ShA) & $\begin{array}{c}39^{\circ} 03^{\prime} 25.9^{\prime \prime} \mathrm{N} \\
8^{\circ} 58^{\prime} 46.3^{\prime \prime} \mathrm{E}\end{array}$ & June 2018 & $\begin{array}{l}\text { Herbarium } \\
\text { CAG } 812\end{array}$ \\
\hline $\begin{array}{l}\text { Silybum } \\
\text { marianum (L.) } \\
\text { Gaertn. }\end{array}$ & Asteraceae & Aerial parts (SmA) & $\begin{array}{c}39^{\circ} 16^{\prime} 51.5^{\prime \prime} \mathrm{N} \\
8^{\circ} 56^{\prime} 01.5^{\prime \prime} \mathrm{E}\end{array}$ & May 2017 & $\begin{array}{l}\text { Herbarium } \\
\text { CAG } 801\end{array}$ \\
\hline Smilax aspera L. & Smilacaceae & Aerial parts (SaA) & $\begin{array}{c}39^{\circ} 10^{\prime} 38.7^{\prime \prime} \mathrm{N} \\
9^{\circ} 22^{\prime} 50.3^{\prime \prime} \mathrm{E}\end{array}$ & May 2017 & $\begin{array}{l}\text { Herbarium } \\
\text { CAG } 1414\end{array}$ \\
\hline $\begin{array}{c}\text { Stachys glutinosa } \\
\text { L. }^{+}\end{array}$ & Lamiaceae & Aerial parts (SgA) & $\begin{array}{c}39^{\circ} 55^{\prime} 46.1^{\prime \prime} \mathrm{N} \\
9^{\circ} 27^{\prime} 10.7^{\prime \prime} \mathrm{E}\end{array}$ & June 2017 & $\begin{array}{l}\text { Herbarium } \\
\text { CAG } 1099\end{array}$ \\
\hline $\begin{array}{c}\text { Tanacetum } \\
\text { audibertii (Req.) } \\
\text { DC }^{* *}\end{array}$ & Asteraceae & Aerial parts $(\mathrm{TaA})$ & $\begin{array}{c}40^{\circ} 02^{\prime} 07.9^{\prime \prime} \mathrm{N} \\
9^{\circ} 17^{\prime} 59.1^{\prime \prime} \mathrm{E}\end{array}$ & August 2018 & $\begin{array}{l}\text { Herbarium } \\
\text { CAG 737/A }\end{array}$ \\
\hline $\begin{array}{c}\text { Thymus herba } \\
\text { barona Loisel } \S\end{array}$ & Lamiaceae & Aerial parts (ThA) & $\begin{array}{c}39^{\circ} 56^{\prime} 01.2^{\prime \prime} \mathrm{N} \\
9^{\circ} 19^{\prime} 56.9^{\prime \prime} \mathrm{E}\end{array}$ & June 2017 & $\begin{array}{l}\text { Herbarium } \\
\text { CAG } 1065\end{array}$ \\
\hline
\end{tabular}

\subsection{Preparation of Plant Extracts for Bioactivity Tests and for ${ }^{1} \mathrm{H}$ NMR Profiling}

A total of $30 \mathrm{mg}$ of dried and powdered plant material were extracted by sonication for $30 \mathrm{~min}$ using $1.5 \mathrm{~mL}$ of $\mathrm{MeOH} / \mathrm{H}_{2} \mathrm{O}(1: 1)$. Subsequently, samples were centrifuged $(1700 \times g)$ for $20 \mathrm{~min}$ and the supernatant was separated from the pellet and dried, firstly in vacuum concentrators (speedVac SPD $101 \mathrm{~b} 230$, Savant, Italy) for $2 \mathrm{~h}$ to remove $\mathrm{MeOH}$, then the residual extracts were freeze-dried overnight to completely remove the residual $\mathrm{H}_{2} \mathrm{O}$, finally yielding the crude extracts. This extraction procedure is ideal to prepare a small quantity of extracts for in vitro bioactivity tests, thus for screenings of a high number of plants, allowing a minimal consumption of both solvents and plant material. The choice of 
the extraction solvents was based on metabolomics works [53,54], where $\mathrm{MeOH} / \mathrm{H}_{2} \mathrm{O}(1: 1)$ turned out as the best choice for first-line extraction of generic plant material, having obtained a broad spectrum of compounds.

Extracts were solubilized in $\mathrm{H}_{2} \mathrm{O}$ to prepare stock solution at a concentration of $1 \mathrm{mg} / \mathrm{mL}$, which was centrifuged for $10 \mathrm{~min}(1700 \times g)$ and used for testing the biological activities.

For ${ }^{1} \mathrm{H}$ NMR profiling, $4 \mathrm{mg}$ of freeze-dried extracts were solubilized in $1 \mathrm{~mL}$ of phosphate buffer (90 mM, pH 6.0) in $\mathrm{D}_{2} \mathrm{O}$ containing standard $0.01 \%$ trimethylsilylpropionic-2,2,3,3- $\mathrm{d}_{4}$ acid sodium salt (TMSP). Samples were centrifuged for $10 \mathrm{~min}(1700 \times g)$ and $700 \mu \mathrm{L}$ of the supernatant were transferred into NMR tubes for the analysis.

\subsection{Fractionation and Cynaropicrin Identification}

To better characterize predominant secondary metabolites from $\mathrm{CycA}$ and $\mathrm{AuL}$, further purification procedures were carried out. The amount of $1 \mathrm{~g}$ of CycA was extracted in $50 \mathrm{~mL}$ of $\mathrm{MeOH} / \mathrm{H}_{2} \mathrm{O}$ (1:1), sonicated for $30 \mathrm{~min}$, and centrifuged for $15 \mathrm{~min}$ in $50 \mathrm{~mL}$ tubes. The supernatant was dried in a rotary evaporator, yielding $92 \mathrm{mg}$ of extract, which was solubilized in $25 \mathrm{~mL}$ of $\mathrm{H}_{2} \mathrm{O}$ and subjected to liquid/liquid partition with $\mathrm{CHCl}_{3}$ ( $25 \mathrm{~mL}$ for three times). The organic phases were collected, anhydrificated using $\mathrm{Na}_{2} \mathrm{SO}_{4}$ anhydrous, filtered, and dried in the rotary evaporator. Cynaropicrin was identified by NMR experiments ( ${ }^{1} \mathrm{H}$ NMR; HMBC, HSQC, COSY, J-res) (Figure S2 and Table A1) from the $\mathrm{CHCl}_{3}$ fraction (yield equal to $21 \mathrm{mg}$ ) solubilized in $\mathrm{CD}_{3} \mathrm{OD}$ at a concentration of $4 \mathrm{mg} / \mathrm{mL}$.

\subsection{NMR Measurement and Analysis}

${ }^{1} \mathrm{H}$ NMR spectra, J-resolved (J-res), ${ }^{1} \mathrm{H}-{ }^{1} \mathrm{H}$ homonuclear, and inverse detected ${ }^{1} \mathrm{H}_{-}{ }^{13} \mathrm{C}$ correlation experiments were recorded at $25^{\circ} \mathrm{C}$ on a Varian Inova $600 \mathrm{MHz}$ NMR instrument (600 MHz operating at the ${ }^{1} \mathrm{H}$ frequency) equipped with an indirect triple resonance probe. $\mathrm{D}_{2} \mathrm{O}$ was used for internal lock for ${ }^{1} \mathrm{H}$ NMR profiling and $\mathrm{CD}_{3} \mathrm{OD}$ for the other measurements.

For all ${ }^{1} \mathrm{H}$ NMR analyses, relaxation delay was $2.0 \mathrm{~s}$, observed pulse $5.80 \mu \mathrm{s}$, number of scans 256, acquisition time $16 \mathrm{~min}$, and spectral width $9595.78 \mathrm{~Hz}$ (corresponding to $\delta 16.0$ ). For ${ }^{1} \mathrm{H} \mathrm{NMR}$ profiling, a presaturation sequence (PRESAT) was used to suppress the residual $\mathrm{H}_{2} \mathrm{O}$ signal at $\delta 4.83$ (power $=-6 \mathrm{~dB}$, presaturation delay $2 \mathrm{~s}$ ).

Spectra were processed by Mestrenova software (Mestrelab Research, Santiago de Compostela, Spain), and the analysis of ${ }^{1} \mathrm{H}$ NMR profiles of extracts was performed based on an in-house library and comparison with literature $[55,56]$. Estimation of metabolites amount in the crude extracts was calculated by comparison of diagnostic signals and TMSP (internal standard) resonating at $\delta 0$.

\subsection{Phenolic and Flavonoid Content}

The assays were performed in a Spectrophotometer Jasco V-530 as described by Mandrone et al. (2019) [8]. Analyses were performed in triplicate.

\subsection{Cell Culture and Treatment}

Human osteosarcoma cells U2OS were cultured in RPMI 1640 medium, supplemented with 10\% fetal bovine serum and $2 \mathrm{mM}$ L-glutamine, at $37{ }^{\circ} \mathrm{C}$ in a humidified atmosphere containing $5 \% \mathrm{CO}_{2}$.

Cells were plated at $1 \times 10^{4}$ cells $/ \mathrm{cm}^{2}$ in Petri dishes and treated with plant extracts after $24 \mathrm{~h}$ for all experiments.

Human umbilical vein endothelial cells (HUVEC) were plated on gelatin-coated tissue culture dishes and maintained in phenol red-free basal medium M200 (Life Technologies, Waltham, Massachusetts) containing 10\% FBS and growth factors (LSGS, Life Technologies, Waltham, Massachusetts) at $37{ }^{\circ} \mathrm{C}$ with $5 \% \mathrm{CO}_{2}$. Cells from passages 3 to 7 were actively proliferating (70\%-90\% confluent) when samples were harvested and analyzed. Dried extracts were dissolved in ultrapure water at $1 \mathrm{mg} / \mathrm{mL}$ and added to cell medium at the appropriate concentration and for the required time depending on the experiments. 


\subsection{MTT Assay}

The cells were seeded in a 96-well plate and treated for 24 and $48 \mathrm{~h}$ with extracts under test in quadruplicate; controls were treated with an equal volume of water.

A total of $20 \mu \mathrm{L}$ of tetrazolium salt $(2.5 \mathrm{mg} / \mathrm{mL})$ in PBS was added to culture medium for $4 \mathrm{~h}$, then the medium was removed and $100 \mu \mathrm{L}$ isopropanol was added to each well. The absorbance at $570 \mathrm{~nm}$ of the solubilized formazan salt was determined by microplate reader (VICTOR3, PerkinElmer Life and Analytical Sciences, Milan, Italy).

$\mathrm{EC}_{50}$ refers to the concentration of extract which results in a $50 \%$ reduction of cell growth, and values for different extracts were obtained by dose-response curve interpolation, using Sigma Plot 10.0 software.

\subsection{Cell Cycle Analysis}

DNA profiles were obtained by cytofluorimetric analysis. After $48 \mathrm{~h}$ of treatment, $1 \times 10^{6}$ cells were pelleted and suspended in trisodium citrate $0.1 \%(\mathrm{~m} / \mathrm{v})$, RNase $0.1 \mathrm{mg} / \mathrm{L}$, Igepal $0.01 \%(v / v)$, propidium iodide (PI) $50 \mathrm{mg} / \mathrm{L}$. After $30 \mathrm{~min}$ at $37^{\circ} \mathrm{C}$ in the dark, cells were analyzed by Bryte HS Biorad cytometer, equipped with Xe-Hg lamp. PI fluorescence was collected on a linear scale at $600 \mathrm{~nm}$ and the DNA distribution was analyzed by the Modifit 5.0 software.

\subsection{Analysis of p53 Expression Levels by Flow Cytometry}

The cells were harvested, washed twice with PBS, fixed with 3\% paraformaldehyde, washed with $0.1 \mathrm{M}$ glycine in PBS, and permeabilized in $70 \%$ ice-cold ethanol. After fixing, the cells were washed with 1\% BSA in PBS and incubated overnight with 1:200 anti-p53 monoclonal antibody (Upstate, MA, USA) in blocking buffer. Then, the cells were washed three times and incubated for $1 \mathrm{~h}$ at room temperature in 1:1000 FITC labeled secondary antibody (Sigma Aldrich, Milan, Italy). Finally, the samples were analyzed by flow cytometry. FITC green fluorescence was analyzed at $525 \mathrm{~nm}$ on a logarithmic scale by WinDMI 2.8 software.

\subsection{Caspase Activity Assay}

The enzymatic activity of caspase 3 was evaluated by using the colorimetric CaspACE assay system (Promega), according to the manufacturer's instructions. Briefly, treated and control cells were detached, centrifuged, and resuspended in lysis buffer at $5 \times 10^{7}$ cells $/ \mathrm{mL}$ concentration. Cells were lysed by three freeze-thaw cycles. Cell lysates were centrifuged and supernatant fraction was collected. In a 96-well plate were added Caspase Assay Buffer (32 $\mu \mathrm{L})$, DMSO $(2 \mu \mathrm{L})$, DTT $100 \mathrm{mM}(10 \mu \mathrm{L})$, deionized water to final volume $(98 \mu \mathrm{L})$, and $2 \mu \mathrm{L}$ of caspase substrate (DEVD-pNA) in each well. After $4 \mathrm{~h}$ of incubation at $37^{\circ} \mathrm{C}$, the absorbance at $405 \mathrm{~nm}$ was measured and the caspase activity was obtained.

\subsection{Fluorescence Microscopy}

The cells were seeded onto slides and treated with plant extracts. After $24 \mathrm{~h}$ of incubation, they were marked with fluorescent dye Hoechst $33,4320.1 \mathrm{mg} / \mathrm{mL}$ for $30 \mathrm{~min}$ at $37^{\circ} \mathrm{C}$. Then, the samples were washed twice with PBS and fixed with 4\% para-formaldehyde in PBS for $20 \mathrm{~min}$ at room temperature in the dark. After two washes in glycine-PBS, samples were embedded in Mowiol and analyzed by a Nikon Eclipse fluorescence microscope.

\subsection{Statistical Analysis}

Values are expressed as the mean \pm SD of three independent experiments (each one performed in triplicate). Statistical analyses were performed using Graph Pad Prism 4 software (La Jolla, CA, USA). For biological assays, the statistical significance of differences among treatment groups was determined by paired Student's T-test. For flavonoids and phenolic content, samples were compared 
by one-way analysis of variance (ANOVA), followed by Tukey's honestly significant difference (HSD) post hoc test, considering significant differences at $p$ values $<0.05$.

\section{Conclusions}

Thirty-five extracts from Sardinian plants were screened for their antitumor potential against U2OS cells. The results showed five plants were endowed with high activity, namely: Arbutus unedo (AuL), Cynara cardunculus (CycA), Centaurea calcitrapa (CcA), Smilax aspera (SaA), and Tanacetum audibertii (TaA), this latter endemic to Sardinia and Corsica and still scantly investigated. The antiproliferative activity and the phytochemical profiles of these five plants were further investigated. All five extracts caused a block of cell cycle in G2/M phase, and treating with CycA and TaA, the percentage of cells in this phase was higher than $50 \%$. The activity of TaA significantly affected p53 expression levels, while CycA activity did not involve this protein. A significant caspase activation was observed especially for CycA, followed by TaA and CcA. On the contrary, AuL and SaA did not induce apoptotic cell death, suggesting cytostatic rather than cytotoxic effects.

Except for AuL, the other four extracts produced a marked cytotoxicity also on human endothelial vein cells, making them interesting for the additional potential to contrast angiogenesis development. On the other hand, the complete inactivity of AuL on the viability of HUVEC cells indicates its selectivity. The phytochemical analysis revealed a high presence of arbutin and flavonoids in this plant, which might be important for the measured bioactivity. Interestingly, three out of five active plants ( $\mathrm{CcA}, \mathrm{CycA}$, and $\mathrm{TaA})$, belong to the Asteraceae family, which is renowned for producing bioactive sesquiterpene lactones; in fact, these compounds were detected by NMR analysis.

This study highlighted the potential use of these plants as active ingredients to develop functional food for chemoprevention or adjuvants in cancer therapy. Further phytochemical and biological studies are ongoing.

Supplementary Materials: The following are available online at http://www.mdpi.com/2223-7747/9/1/26/s1, Figure S1: Comparison between ${ }^{1} \mathrm{H}$ NMR profiles of Arbutus unedo fruits (AuF) and leaves extracts (AuL), Figure S2: ${ }^{1} \mathrm{H}$ NMR of CycA chloroform fraction. Figure S3. COSY and HSQC experiment of $\gamma$-lactone derivative present in CcA, Figure S4: Superimposed HSQC (red and blue dots) and HMBC (green dots) spectra of $\gamma$-lactone derivative present in CcA, Figure S5: Comparison among ${ }^{1} \mathrm{H}$ NMR of the three species of Centaurea, C. calcitrapa (CcA), C. horrida (ChA), C. napifolia (CnA), Figure S6: Total phenolic A) and flavonoid content B) of the five plant extracts, Table S1: $\mathrm{EC}_{50}$ values and respective $95 \%$ confidence intervals of the most active plants extracts in $\mathrm{U} 2 \mathrm{OS}$ cells, determined by the MTT assay, Table S2: Spectral references of the diagnostic signals of the main metabolites detected by ${ }^{1} \mathrm{H}$ NMR profiling in the five most active plants.

Author Contributions: Conceptualization, M.M. and C.C.; methodology, M.M., C.C., and C.S.; software, E.M.; validation, M.M., C.C., and E.M.; formal analysis, I.C., G.P., and V.B.; investigation, I.C., G.P., and C.S.; resources, C.S., F.P.; data curation, M.M., C.C., and F.P.; writing—original draft preparation, M.M..; writing-review and editing, C.C.; visualization, E.M.; supervision, F.P.; project administration, F.P.; funding acquisition, F.P. and C.C. All authors have read and agreed to the published version of the manuscript.

Funding: This research received no external funding.

Acknowledgments: The authors would like to thank Stefano Iotti and Giovanna Farruggia from the University of Bologna for their precious contribution to the discussion of the data presented in this manuscript.

Conflicts of Interest: The authors declare no conflict of interest. 


\section{Appendix A}

Table A1. NMR spectral references for cynaropicrin. Spectra of the purified fraction were measured in $\mathrm{CD}_{3} \mathrm{OD}$. Splitting patterns and coupling constants were determined by J-res experiment.

\begin{tabular}{|c|c|c|c|c|}
\hline Position & ${ }^{1} \mathrm{H}(\delta ; \mathrm{J})$ & ${ }^{13} \mathrm{C}(\delta)$ & НМВС & COSY \\
\hline 1 & $\begin{array}{l}3.00(\text { ddd; } \mathrm{J}=11.53 ; \\
\quad 10.65 \mathrm{~Hz} ; 6.84)\end{array}$ & 46.22 & $\begin{array}{c}39.78 ; 51.32 ; 74.18 ; 118.11 \\
142.84\end{array}$ & $2.09 ; 1.74 ; 2.88$ \\
\hline $2 a$ & $\begin{array}{l}2.09(\mathrm{ddd} ; \mathrm{J}=13.14 ; \\
\quad 7.50 ; 6.84 \mathrm{~Hz})\end{array}$ & 39.78 & $46.22 ; 51.32 ; 74.18 ; 142.84$ & $1.74 ; 3.00 ; 4.49$ \\
\hline $2 b$ & $\begin{array}{l}1.74 \text { (ddd; J = 13.14; } \\
\quad 11.53 ; 8.80 \mathrm{~Hz})\end{array}$ & 39.78 & $46.22 ; 74.18 ; 152.92$ & $2.09 ; 3.00 ; 4.49$ \\
\hline 3 & $\begin{array}{c}4.49(\mathrm{dd} ; \mathrm{J}=8.80 \\
7.60 \mathrm{~Hz})\end{array}$ & 74.18 & 152.92 & $2.09 ; 1.74 ; 5.43 ; 5.64$ \\
\hline 4 & - & 152.92 & - & - \\
\hline 5 & $\begin{array}{c}2.88(\text { ddd; } \mathrm{J}=10.65 ; \\
9.21 \mathrm{~Hz})\end{array}$ & 51.32 & 79.81 & $3.00 ; 4.33 ; 4.91 ; 5.33$ \\
\hline 6 & $\begin{array}{c}4.33(\mathrm{dd} ; \mathrm{J}=11.06 \\
8.89 \mathrm{~Hz})\end{array}$ & 79.81 & 75.15 & $2.88 ; 3.27$ \\
\hline 7 & $3.27(\mathrm{~m})$ & 41.48 & ov. & $4.33 ; 5.15 ; 6.12 ; 5.64$ \\
\hline 8 & $5.15(\mathrm{~m})$ & 75.15 & ov. & 3.27 \\
\hline $9 a$ & $\begin{array}{c}2.73(\mathrm{dd} ; \mathrm{J}=14.65 \\
5.26 \mathrm{~Hz})\end{array}$ & 37.14 & $118.11 ; 142.84$ & $2.40 ; 4.91 ; 5.15$ \\
\hline $9 b$ & $\begin{array}{c}2.40(\mathrm{dd} ; \mathrm{J}=14.65 \\
3.50 \mathrm{~Hz})\end{array}$ & 37.14 & $118.11 ; 142.84$ & $2.73 ; 4.91 ; 5.15$ \\
\hline 10 & - & 142.84 & - & - \\
\hline 11 & - & 138.77 & - & - \\
\hline 12 & - & 170.01 & - & - \\
\hline $13 a$ & $6.12(\mathrm{~d} ; \mathrm{J}=3.30 \mathrm{~Hz})$ & 121.96 & $41.48 ; 138.77 ; 170.01$ & $3.27 ; 5.64$ \\
\hline $13 b$ & $5.64(\mathrm{~d} ; \mathrm{J}=3.30 \mathrm{~Hz})$ & 121.96 & $41.48 ; 138.77 ; 170.01$ & $3.27 ; 6.12$ \\
\hline $14 a$ & $5.14(\mathrm{~d} ; \mathrm{J}=2.09 \mathrm{~Hz})$ & 118.11 & $37.14 ; 46.22 ; 142.84$ & $2.40 ; 2.73 ; 4.91$ \\
\hline $14 b$ & $4.91(\mathrm{~d} ; \mathrm{J}=2.09 \mathrm{~Hz})$ & 118.11 & $37.14 ; 46.22 ; 142.84$ & $2.40 ; 2.73 ; 5.14$ \\
\hline $15 a$ & $5.43(\mathrm{~d} ; \mathrm{J}=1.97 \mathrm{~Hz})$ & 122.36 & $51.32 ; 74.18 ; 152.92$ & $2.88 ; 4.49 ; 5.33$ \\
\hline $15 b$ & $5.33(\mathrm{~d} ; \mathrm{J}=1.97 \mathrm{~Hz})$ & 122.36 & $51.32 ; 74.18 ; 152.92$ & $2.88 ; 4.49 ; 5.43$ \\
\hline $\mathbf{1}^{\prime}$ & - & 165.28 & - & - \\
\hline $2^{\prime}$ & - & 140.80 & - & - \\
\hline $3{ }^{\prime} \mathbf{a}$ & $6.30(\mathrm{~d} ; \mathrm{J}=1.40 \mathrm{~Hz})$ & 125.70 & $61.73 ; 140.80 ; 165.28$ & $4.30 ; 5.97$ \\
\hline $3^{\prime} b$ & $5.97(\mathrm{~d} ; \mathrm{J}=1.40 \mathrm{~Hz})$ & 125.70 & $61.73 ; 140.80 ; 165.28$ & $4.30 ; 6.30$ \\
\hline $4^{\prime}$ & $4.30(\mathrm{~s})$ & 61.73 & $125.70 ; 140.80 ; 165.28$ & $5.97 ; 6.30$ \\
\hline
\end{tabular}

\section{References}

1. Bolzani da Silva, V.; Valli, M.; Pivatto, M.; Viegas, C. Natural products from Brazilian biodiversity as a source of new models for medicinal chemistry. Pure Appl. Chem. 2012, 84, 1837-1846. [CrossRef]

2. Henrich, C.J.; Beutler, J.A. Matching the power of high throughput screening to the chemical diversity of natural products. Nat. Prod. Rep. 2013, 30, 1284-1298. [CrossRef] [PubMed]

3. Cañadas, E.; Giuseppe, F.; Peñas, J.; Lorite, J.; Mattana, E.; Bacchetta, G. Hotspots within hotspots: Endemic plant richness, environmental drivers, and implications for conservation. Biol. Conserv. 2014, 170, $282-291$. [CrossRef]

4. Fois, M.; Fenu, G.; Cañadas, E.M.; Bacchetta, G. Disentangling the influence of environmental and anthropogenic factors on the distribution of endemic vascular plants in Sardinia. PLoS ONE 2017, 12, e0182539. [CrossRef]

5. Bartolucci, F.; Peruzzi, L.; Galasso, G.; Albano, A.; Alessandrini, A.; Ardenghi, N.M.G.; Astuti, G.; Bacchetta, G.; Ballelli, S.; Banfi, E.; et al. An updated checklist of the vascular flora native to Italy. Plant Biosyst. 2018, 152, 179-303. [CrossRef] 
6. Fenu, G.; Fois, M.; Cañadas, E.M.; Bacchetta, G. Using endemic-plant distribution, geology and geomorphology in biogeography: The case of Sardinia (Mediterranean Basin). Syst. Biodivers. 2014, 12, 181-193. [CrossRef]

7. Cagno, V.; Sgorbini, B.; Sanna, C.; Cagliero, C.; Ballero, M.; Civra, A.; Donalisio, M.; Bicchi, C.; Lembo, D.; Rubiolo, P. In vitro anti-herpes simplex virus-2 activity of Salvia desoleana Atzei \& V. Picci essential oil. PLoS ONE 2017, 12, e0172322. [CrossRef]

8. Mandrone, M.; Bonvicini, F.; Lianza, M.; Sanna, C.; Maxia, A.; Gentilomi, G.A.; Poli, F. Sardinian plants with antimicrobial potential. Biological screening with multivariate data treatment of thirty-six extracts. Ind. Crop. Prod. 2019, 137, 557-565. [CrossRef]

9. Sanna, C.; Scognamiglio, M.; Fiorentino, A.; Corona, A.; Graziani, V.; Caredda, A.; Cortis, P.; Montisci, M.; Ceresola, E.; Canducci, F.; et al. Prenylated phloroglucinols from Hypericum scruglii, an endemic species of Sardinia (Italy), as new dual HIV-1 inhibitors effective on HIV-1 replication. PLOS ONE 2018, 13, e0195168. [CrossRef]

10. Sanna, C.; Rigano, D.; Corona, A.; Piano, D.; Formisano, C.; Farci, D.; Franzini, G.; Ballero, M.; Chianese, G.; Tramontano, E.; et al. Dual HIV-1 reverse transcriptase and integrase inhibitors from Limonium morisianum Arrigoni, an endemic species of Sardinia (Italy). Nat. Prod. Res. 2019, 33, 1798-1803. [CrossRef]

11. Roy, A.; Ahuja, S.; Bharadvaja, N. A review on medicinal plants against cancer. J. Plant. Sci. Agric. Res. 2017, 2, 1008.

12. Moten, A.; Schafer, D.; Ferrari, M. Redefining global health priorities: Improving cancer care in developing settings. J. Glob. Health 2014, 4. [CrossRef] [PubMed]

13. Mokhtari, R.B.; Homayouni, T.S.; Baluch, N.; Morgatskaya, E.; Kumar, S.; Das, B.; Yeger, H. Combination therapy in combating cancer. Oncotarget 2017, 8, 38022-38043. [CrossRef] [PubMed]

14. Zuazo-Gaztelu, I.; Casanovas, O. Unraveling the role of angiogenesis in cancer ecosystems. Front. Oncol. 2018, 8, 248. [CrossRef] [PubMed]

15. Sun, L.R.; Zhou, W.; Zhang, H.M.; Guo, Q.S.; Yang, W.; Li, B.J.; Sun, Z.H.; Gao, S.H.; Cui, R.J. Modulation of multiple signaling pathways of the plant-derived natural products in cancer. Front. Oncol. 2019, 9, 1153. [CrossRef]

16. Dutta, R.; Khalil, R.; Green, R.; Mohapatra, S.S.; Mohapatra, S. Withania somnifera (Ashwagandha) and withaferin A: Potential in integrative oncology. Int. J. Mol. Sci. 2019, 20, 5310. [CrossRef]

17. Remadevi, V.; Mohan Lathika, L.; Sasikumar Sujatha, A.; Sreeharshan, S. Ficus extract-A promising agent for antimammary tumorigenesis: A review on current status and future possibilities. Phytother. Res. 2019, 33, 1597-1603. [CrossRef]

18. Chen, P.; Li, C.; Li, X.; Li, J.; Chu, R.; Wang, H. Higher dietary folate intake reduces the breast cancer risk: A systematic review and meta-analysis. Br. J. Cancer 2014, 110, 2327-2338. [CrossRef]

19. Toledo, E.; Salas-Salvadó, J.; Donat-Vargas, C.; Buil-Cosiales, P.; Estruch, R.; Ros, E.; Corella, D.; Fitó, M.; Hu, F.B.; Arós, F.; et al. Mediterranean diet and invasive breast cancer risk among women at high cardiovascular risk in the PREDIMED Trial: A randomized clinical trial. JAMA Intern. Med. 2015, 175, 1752-1760. [CrossRef]

20. Crew, K.D.; Brown, P.; Greenlee, H.; Bevers, T.B.; Arun, B.; Hudis, C.; McArthur, H.L.; Chang, J.; Rimawi, M.; Vornik, L.; et al. Phase IB randomized, double-blinded, placebo-controlled, dose escalation study of polyphenon $\mathrm{E}$ in women with hormone receptor-negative breast cancer. Cancer Prev. Res. (Phila) 2012, 5, 1144-1154. [CrossRef]

21. Hui, C.; Qi, X.; Qianyong, Z.; Xiaoli, P.; Jundong, Z.; Mantian, M. Flavonoids, flavonoid subclasses and breast cancer risk: A meta-analysis of epidemiologic studies. PLoS ONE 2013, 8, e54318. [CrossRef] [PubMed]

22. Ballero, M.; Floris, R.; Poli, F. Le piante utilizzate nella medicina popolare nel territorio di Laconi (Sardegna centrale). Boll. Soc. Sarda Sci. Nat. 1997, 31, 207-229.

23. Loi, M.C.; Maxia, L.; Maxia, A. Ethnobotanical Comparison between the Villages of Escolca and Lotzorai (Sardinia, Italy). J. Herbs Spices Med. Plants 2005, 11, 67-84. [CrossRef]

24. Ballero, M.; Poli, F.; Sacchetti, G.; Loi, M.C. Ethnobotanical research in the territory of Fluminimaggiore (south-western Sardinia). Fitoterapia 2001, 72, 788-801. [CrossRef]

25. Ballero, M.; Sacchetti, G.; Poli, F. Plants in folk medicine in the territory of Perdasdefogu (Central Sardinia, Italy). Allonia 1997, 35, 57-164. 
26. Bruni, A.; Ballero, M.; Poli, F. Quantitative ethnopharmacological study of the Campidano Valley and Urzulei district, Sardinia, Italy. J. Ethnopharmacol. 1997, 57, 97-124. [CrossRef]

27. Loi, M.C.; Frailis, L.; Maxia, A. Le piante utilizzate nella medicina popolare nel territorio di Gesturi (Sardegna centro-meridionale). Atti. Soc. Tosc. Sci. Nat. Mem. Ser. B 2002, 109, 167-176.

28. Loi, M.C.; Poli, F.; Sacchetti, G.; Selenu, M.B.; Ballero, M. Ethnopharmacology of Ogliastra (Villagrande Strisaili, Sardinia, Italy). Fitoterapia 2004, 75, 277-295. [CrossRef]

29. Leonti, M.; Casu, L.; Sanna, F.; Bonsignore, L. A comparison of medicinal plant use in Sardinia and Sicily-De Materia Medica revisited? J. Ethnopharmacol. 2009, 121, 255-267. [CrossRef]

30. Ballero, M.; Bruni, A.; Sacchetti, G.; Poli, F. Le piante utilizzate nella medicina popolare nel comune di Tempio Pausania (Sardegna settentrionale). Acta Phytother. 1997, 1, $23-29$.

31. Ballero, M.; Poli, F. Plants used in folk medicine of Monteleone (Northern Sardinia). Fitoterapia 1998, 69, 52-64.

32. Atzei, A.D. Le Piante Nella Tradizione Popolare Della Sardegna; Carlo Delfino: Sassari, Italy, 2003.

33. Palmese, M.T.; Manganelli, R.E.; Tomei, P.E. An ethno-pharmacobotanical survey in the Sarrabus district (south-east Sardinia). Fitoterapia 2001, 72, 619-643. [CrossRef]

34. Hientz, K.; Mohr, A.; Bhakta-Guha, D.; Efferth, T. The role of p53 in cancer drug resistance and targeted chemotherapy. Oncotarget 2016, 8, 8921-8946. [CrossRef] [PubMed]

35. Sharma, K.; Vu, T.; Cook, W.; Naseri, M.; Zhan, K.; Nakajima, W.; Harada, H. p53-independent Noxa induction by cisplatin is regulated by ATF3/ATF4 in head and neck squamous cell carcinoma cells. Mol. Oncol. 2018, 12, 788-798. [CrossRef] [PubMed]

36. Gupta, K.; Thakur, V.S.; Bhaskaran, N.; Nawab, A.; Babcook, M.A.; Jackson, M.W.; Gupta, S. Green Tea Polyphenols Induce p53-Dependent and p53- Independent Apoptosis in Prostate Cancer Cells through Two Distinct Mechanisms. PLoS ONE 2012, 7, e52572. [CrossRef] [PubMed]

37. Tsang, W.P.; Chau, S.P.Y.; Kong, S.K.; Fung, K.P.; Kwok, T.T. Reactive oxygen species mediate doxorubicin induced p53-independent apoptosis. Life Sci. 2003, 73, 2047-2058. [CrossRef]

38. Shalini, S.; Dorstyn, L.; Dawar, S.; Kumar, S. Old, new and emerging functions of caspases. Cell Death Differ. 2015, 22, 526-539. [CrossRef]

39. Folkman, J. Fighting cancer by attacking its blood supply. Sci. Am. 1996, 275, 150-154. [CrossRef]

40. Wu, J.-G.; Ma, L.; Lin, S.; Wu, Y.; Yi, J.; Yang, B.; Wu, J.-Z.; Wong, K. Anticancer and anti-angiogenic activities of extract from Actinidia eriantha Benth root. J. Ethnopharmacol. 2017, 203, 1-10. [CrossRef]

41. Morgado, S.; Morgado, M.; Plácido, A.I.; Roque, F.; Duarte, A.P. Arbutus unedo L.: From traditional medicine to potential uses in modern pharmacotherapy. J. Ethnopharmacol. 2018, 225, 90-102. [CrossRef]

42. Curti, V.; Di Lorenzo, A.; Dacrema, M.; Xiao, J.; Nabavi, S.M.; Daglia, M. In vitro polyphenol effects on apoptosis: An update of literature data. SeminCancer Biol. 2017, 46, 119-131. [CrossRef] [PubMed]

43. Jiang, L.; Wang, D.; Zhang, Y.; Li, J.; Wu, Z.; Wang, Z.; Wang, D. Investigation of the pro-apoptotic effects of arbutin and its acetylated derivative on murine melanoma cells. Int. J. Mol. Med. 2018, 41, 1048-1054. [CrossRef] [PubMed]

44. Choi, Y.H.; van Spronsen, J.; Dai, Y.; Verberne, M.; Hollmann, F.; Arends, I.W.C.E.; Witkamp, G.-J.; Verpoorte, R. Are natural deep eutectic solvents the missing link in understanding cellular metabolism and physiology? Plant Physiol. 2011, 156, 1701-1705. [CrossRef] [PubMed]

45. Lepore, S.M.; Maggisano, V.; Lombardo, G.E.; Maiuolo, J.; Mollace, V.; Bulotta, S.; Russo, D.; Celano, M. Antiproliferative effects of cynaropicrin on anaplastic thyroid cancer cells. Endocr. Metab. Immune 2019, 19, 59-66. [CrossRef] [PubMed]

46. Bruno, M.; Bancheva, S.; Rosselli, S.; Maggio, A. Sesquiterpenoids in subtribe Centaureinae (Cass.) Dumort (tribe Cardueae, Asteraceae): Distribution, (13) C NMR spectral data and biological properties. Phytochemistry 2013, 95, 19-93. [CrossRef]

47. Genovese, C.; Brundo, M.; Toscano, V.; Tibullo, D.; Puglisi, F.; Raccuia, S. Effect of Cynara extracts on multiple myeloma cell lines. Acta Hortic. 2016, 1147, 113-118. [CrossRef]

48. Ramos, P.A.B.; Guerra, Â.R.; Guerreiro, O.; Santos, S.A.O.; Oliveira, H.; Freire, C.S.R.; Silvestre, A.J.D.; Duarte, M.F. Antiproliferative effects of Cynara cardunculus L. var. altilis (DC) lipophilic extracts. Int. J. Mol. Sci. 2016, 18, 63. [CrossRef]

49. Erol-Dayi, Ö.; Pekmez, M.; Bona, M.; Aras-Perk, A.; Arda, N. Total phenolic contents, antioxidant activities cytotoxicity of three Centaurea species: C. calcitrapa subsp. calcitrapa, C. ptosimopappa, C. spicata. Free Radic. Antiox. 2011, 1, 31-36. [CrossRef] 
50. Ivanova, A.; Mikhova, B.; Batsalova, T.; Dzhambazov, B.; Kostova, I. New furostanol saponins from Smilax aspera L. and their in vitro cytotoxicity. Fitoterapia 2011, 82, 282-287. [CrossRef]

51. Longo, L.; Vasapollo, G. Extraction and identification of anthocyanins from Smilax aspera L. berries. Food Chem. 2006, 94, 226-231. [CrossRef]

52. Maxia, A.; Sanna, C.; Piras, A.; Porcedda, S.; Danilo, F.; Gonçalves, M.; Cavaleiro, C.; Salgueiro, L. Chemical composition and biological activity of Tanacetum audibertii (Req.) DC. (Asteraceae), an endemic species of Sardinia Island, Italy. Ind. Crop. Prod. 2015, 65, 472-476. [CrossRef]

53. Kim, H.K.; Choi, Y.H.; Verpoorte, R. NMR-based metabolomic analysis of plants. Nat. Protoc. 2010, 5, 536-549. [CrossRef] [PubMed]

54. Mandrone, M.; Coqueiro, A.; Poli, F.; Antognoni, F.; Choi, Y.H. Identification of a collagenase-inhibiting flavonoid from Alchemilla vulgaris using NMR-based metabolomics. Planta Med. 2018, 84, 941-946. [CrossRef] [PubMed]

55. Mandrone, M.; Scognamiglio, M.; Fiorentino, A.; Sanna, C.; Cornioli, L.; Antognoni, F.; Bonvicini, F.; Poli, F. Phytochemical profile and $\alpha$-glucosidase inhibitory activity of Sardinian Hypericum scruglii and Hypericum Hircinum. Fitoter 2017, 120, 184-193. [CrossRef] [PubMed]

56. Mandrone, M.; Antognoni, F.; Aloisi, I.; Potente, G.; Poli, F.; Cai, G.; Faleri, C.; Parrotta, L.; Del Duca, S. Compatible and incompatible pollen-styles interaction in Pyrus communis L. show different transglutaminase features, polyamine pattern and metabolomics profiles. Front. Plant. Sci. 2019, 10, 741. [CrossRef] [PubMed]

(C) 2019 by the authors. Licensee MDPI, Basel, Switzerland. This article is an open access article distributed under the terms and conditions of the Creative Commons Attribution (CC BY) license (http://creativecommons.org/licenses/by/4.0/). 